\title{
CLÁUSULAS DE NO COMPETENCIA, VALIDEZ EN EL ORDENAMIENTO JURIDICO COLOMBIANO *
}

Rafael Leonardo Páez Fuentes ${ }^{1}$

SUMARIO: RESUMEN - INTRODUCCION - 1. Definición 2. Validez

Constitucional. 3. Validez Desde El Derecho Privado Y De La Competencia. 3.1. Objeto Del Derecho De La Competencia. 3.2. Prácticas Restrictivas De La Competencia. 3.3. Tratamiento En El Derecho Comparado 3.4 Tratamiento En El Derecho Colombiano. 3.5. Tratamiento En La Comunidad Andina. 4 Requisitos Para La Validez. 4.1 La Clausula Inhibitoria De La Competencia Debe Ser Accesoria Y Subordinada. 4.2. La Clausula Inhibitoria De La Competencia Debe Ser Necesaria.4.3 La Clausula Inhibitoria De La Competencia Debe Ser Proporcionada. 4.3.1 Duración. 4.3.2. Ámbito Geográfico. 4.3.3. Alcance. 4.3.4. Contenido. 5. Régimen de Responsabilidad - CONCLUSIONES - BIBLIOGRAFIA

\section{RESUMEN}

Las clausulas de no competencia, habían sido consideradas por la doctrina colombiana como restricciones indebidas de la competencia e ilegales per se, sin embargo esta tendencia ha ido variando y dando paso a la aplicación de la regla

\footnotetext{
*El presente artículo surge como resultado de la investigación desarrollada al interior del grupo de investigación en la Maestría en Derecho Contractual Público y Privado de la Universidad Santo Tomas, Bogotá D.C.

${ }^{1}$ Abogado. USTA, Especialista en Derecho Financiero. U Rosario.
} 
de la razón, y la doctrina de las restricciones accesorias de la competencia, este trabajo analiza la posibilidad de pactar clausulas de no competencia dentro de operaciones mercantiles y los requisitos que éstas deben cumplir dentro del ordenamiento jurídico Colombiano para ser consideradas admisibles, haciendo un estudio desde el punto de vista constitucional, y del derecho norteamericano y europeo, para determinar su validez dentro del derecho privado y de la competencia Colombiano.

Palabras Clave:

Clausulas De No Competencia, Restricciones Accesorias, Regla De La Razón,

ABSTRACT

The non-compete clauses, had been considered by the Colombian doctrine, as undue restrictions on competition and illegal per se, however, this trend has been changing and giving way to the application of the rule of reason and the doctrine of ancillary restraints, This paper analyzes the possibility of negotiating non-compete clauses in business operations and the requirements they must meet within the Colombian legal system to be considered admissible, doing a study from the standpoint of constitutional law and American and European to determine their validity under private law and antitrust of Colombia.

KEY WORDS

Non-Compete clauses, Ancillary Restrictions, Rule of Reason 


\section{INTRODUCCION}

La globalización y el desarrollo tecnológico, han dado surgimiento a nuevas formas negóciales, a su vez este mercado contemporáneo exige mayores grados de conocimiento, que le permitan tanto al individuo como a las empresas un mayor nivel de especialización y el desarrollo de estrategias, secretos e invenciones que les permitan satisfacer a sus clientes, ser competitivos, y mantenerse en buena posición en el mercando, no solo nacional sino mundial.

Esta necesidad ha hecho que muchas compañías inviertan grandes sumas de dinero en el desarrollo de estrategias de mercado, técnico, ajustes de procesos, formación técnica y profesional, el " know-how", canales de distribución proveedores, tecnología etc. Sin embargo este esfuerzo puede verse seriamente amenazado por algunos de sus empleados, socios, o aliados comerciales, quienes pueden ser seducidos bien sea por otras empresas o por iniciativas emprendedoras que les permitan desvincularse de la relación subordinada, para aplicar dichas estrategias o conocimientos en empresas de la competencia o en su propio negocio.

La necesidad de proteger su inversión y conocimiento ha conducido al desarrollo de estipulaciones contractuales que permitan tener una garantía de que este individuo no utilice las herramientas dadas por su capacitador, la información o el conocimiento adquirido sobre el negocio, para competir contra este en el mismo ramo, estipulaciones que conocemos hoy en día con el nombre de clausulas de no 
competencia. Es decir estipulaciones por las cuales una persona se obliga para con otra no realizar cierto tipo de actividad económica o empresarial en este ramo de los negocios.

En el derecho mercantil extranjero e internacional, es común encontrar estipulaciones de no competencia en el desarrollo de sociedades, la compra venta o arrendamiento de empresas o establecimientos de comercio, la celebración de contratos de licenciamiento y franquicia entre otros, que deben asegurar de alguna manera que el administrador, socio, vendedor o franquiciado no inicie o propicie actividades de competencia que comprometan la inversión de la persona jurídica, el adquirente o el fanquiciador.

A su vez en la compraventa de empresas o de establecimientos de comercio en los cuales se incluye el derecho a la clientela además de KnqwHow es común estipular clausulas mediante las cuales el vendedor se obliga a no iniciar las mismas actividades empresariales o abrir establecimientos de comercio en lugar determinado de manera indefinida o por un tiempo que permita al adquirente recuperar su inversión, generar utilidad y mantenerse.

En los contratos de franquicia cobran importancia este tipo de clausulas entendiendo que uno de los elementos esenciales de este negocio radica en que el franquiciador entrega a su fanquiciado una serie de conocimientos técnicos desarrollados por este para la elaboración del producto prestación del servicio o ejecución del negocio sobre los cuales se establece el Knowhow, en este contrato como es lógico se estipula una clausula que limita el uso del knowhow que le 
cedió este franquiciador para desarrollar su propio negocio, durante la relación contractual y aun en la etapa post contractual.

Como se puede apreciar de este primer vistazo la utilización de clausulas de no competencia puede tener diversas modalidades y comprender actuaciones contractuales de distintas áreas del derecho, y hoy por hoy este tipo de estipulaciones son aceptadas en muchos ordenamientos jurídicos. $Y$ aunque el nuestra legislación solamente se ocupa de restringir estos pactos en algunos casos, no por ello se puede descartar su validez en ciertas circunstancias y es menester también procurar evaluar el desarrollo que sobre el tema han dado otros ordenamientos jurídicos para determinar la conveniencia o no de las limitaciones que sobre este tipo de pactos existen.

Mediante el presente documento se pretende analizar la posibilidad de pactar este tipo de clausulas dentro del ordenamiento jurídico Colombiano actual, las posiciones que sobre este particular han tomado otros ordenamientos jurídicos para el estudio de este tema, que permitan fijar los límites de estas estipulaciones contractuales y algunos presupuestos para su validez.

Iniciaremos por un estudio desde el punto de vista constitucional, para determinar posteriormente su validez dentro del derecho privado y de la competencia colombiano, y finalmente estableceremos los requisitos que deben tener este tipo de clausulas para ser consideradas admisibles dentro del ordenamiento jurídico Colombiano. 


\section{CLÁUSULAS DE NO COMPETENCIA, VALIDEZ EN EL ORDENAMIENTO JURIDICO COLOMBIANO}

\section{Definición}

El reconocido jurista mexicano(Adame Goddard, 2001, pág. 688)define a las clausulas de no competencia como, cláusulas o pactos incluidos en un contrato por el que una persona asume la obligación de no competir en un cierto mercado con otra. (Pascual Y Vicente, 2002, pág. 136) Define las cláusulas accesorias de no competencia como aquellas que establecen dos empresas con el objetivo de no disputar la clientela en un mercado determinado durante un cierto tiempo o indefinidamente. Este tipo de acuerdo se precisa en una cláusula de un contrato principal, del cual es accesorio, y persigue frecuentemente asegurar el cumplimiento de las estipulaciones contenidas en aquél

El (Reglamento no 2790/1999 CE, 1999) relativo a la aplicación del apartado 3 del artículo 81 del Tratado CE a determinadas categorías de acuerdos verticales y prácticas concertadas señala que entenderá por "Cláusula de no competencia", cualquier obligación directa o indirecta que prohíba al comprador fabricar, adquirir, vender o revender bienes o servicios que compitan con los bienes o servicios contractuales..."

Podría definirse entonces de una manera general la clausula de no competencia, como un acuerdo mediante el cual una persona se obliga para con otra a no competir directa o indirectamente con esta última, en la actividad económica que desarrolla, durante la vigencia del contrato que los vincula o posterior a su 
vencimiento, es decir a no realizar cierta actividad empresarial o profesional, como distribuir, comercializar, transformar, producir, o prestar sus servicios, durante un cierto tiempo y en un territorio delimitado. Además de la prohibición se apareja a esta clausula, una sanción de tipo pecuniario o indemnizatorio en caso de incumplimiento de tal estipulación.

\section{Validez Constitucional}

Para comenzar nuestro análisis de validez, debemos señalar que en Colombia ha sido muy poca la referencia jurisprudencial respecto a la eficacia de este tipo de cláusulas, es por ello que partiremos de los análisis que hiciera la Corte Suprema de Justicia quien considero su validez desde el ámbito laboral, sin embargo en otros ámbitos como el comercial el tema no ha sido aun objeto de estudio.

La constitución Política de Colombia (art .25,), señala que "el trabajo es un derecho y una obligación social y goza, en todas sus modalidades de la protección del estado" , el derecho al trabajo estaba igualmente consagrado en la constitución política de 1886 en el artículo 17 como una obligación social, por ello la Corte Suprema de Justicia Sala Plena en (Sentencia, 1973) ${ }^{2}$ declaró inexequible la parte del artículo 44 del código sustantivo del trabajo que permitía la estipulación con trabajadores de clausulas de no competencia post contractuales, pues esta estipulación a su juicio restringía la obligación social de trabajar. Lo que pone de presente que en cuestiones laborales las clausulas de no competencia son nulas

${ }^{2}$ Sentencia (Corte Suprema de Justicia de Colombia Sala Plena 18 de junio de 1973) 
en el derecho Colombiano a diferencia de otros ordenamientos donde esta clases de clausulas han tenido validez con cierto tipo de restricciones, pero principalmente han sido aceptadas como una manera de garantizar la protección del KnowHow, de actos desleales del empleado para con el empresario empleador, como el caso del (Codice Civile , 1942) Italiano en sus artículos 2125 y 2596, La Corte de Casación Francesa en (Sentencia , 2002) 35eñaló que una cláusula de no competencia laboral sólo es lícita si es indispensable para proteger los intereses legítimos de la empresa, está limitada en el tiempo y el espacio que tiene en cuenta la especificidad de la relación de trabajo del empleado, e incluye una obligación para el empleador a pagar al empleado una contribución financiera

Pero las clausulas de no competencia no solo tienen aplicaciones en el ámbito laboral, donde resultarían ineficaces, según los señalado por la Corte y la ley Colombiana, sino en otros escenarios donde no necesariamente se restringe el ejercicio del derecho al trabajo, como en los procesos de integración Empresarial, la compraventa de empresas y establecimientos de comercio, la celebración de contratos de franquicia y agencias entre otros donde la clausula tendrá que analizarse a la luz del derecho a la libertad económica, la libre iniciativa privada y la libre competencia, derechos que se encuentran consagrados en el artículo art 333 (Constitucion Política de Colombia , 1991)

${ }^{3}$ Sentencia, Dalloz, 2002.2491 (Cour de Cassation français 10 de julio de 2002) 
Al respecto el Consejo de Estado Colombia en (Sentencia , 2001) ${ }^{4}$ indicó que La libre competencia económica es la posibilidad que tiene cualquier persona de participar en determinada actividad económica como oferente o demandante, con libertad de decidir cuándo entrar y salir de un mercado sin que exista nadie que pueda imponer, individual o conjuntamente, condiciones en las relaciones de intercambio.

La libertad de empresa ha sido definida por la jurisprudencia la Corte Constitucional, (Sentencia Constitucionalidad, 1996) ${ }^{5}$ como un derecho de de toda persona para de ejercer y desarrollar una determinada actividad económica, de acuerdo con el modelo económico u organización institucional

En cuanto a los limites de los derechos a libertad económica y la libre iniciativa privada la Corte Constitucional(Sentencia Constitucionalidad, 1996) ${ }^{6}$ ha sustentado que el derecho de la libertad económica, no es absoluto, sino que aparece limitado por los derechos de los demás, la prevalencia del interés social, el ambiente y el patrimonio cultural de la Nación, la función social de la empresa y la libre competencia económica.

Igualmente esta misma corporación(Sentencia de Constitucionalidad , 1998) ${ }^{7}$ ha reconocido al contrato como un instrumento indispensable para el desarrollo de la

\footnotetext{
${ }^{4}$ Sentencia , Radicación número: 54001-23-31-000-2000-1749-0 (Consejo de Estado de Colombia 24 de agosto de 2001)

${ }^{5}$ Sentencia Constitucionalidad, C524 (Corte Constitucional 1996)

${ }^{6}$ Sentencia Constitucionalidad, C-093 (Corte Constitucional de Colombia 1996)

${ }^{7}$ Sentencia de Constitucionalidad , c- 624 (Corte Constitucional de Colombia 1998)
} 
libertad de empresa concluyendo que la libertad negocial, es un modo de estar y de actuar en sociedad y de ser libre y, por todo ello, es elemento que se encuentra en la base misma del derecho constitucional

En conclusión la corte ha señalado que la libertad contractual se encuentra amparada constitucionalmente, pero le impone límites que son los mismos de la libertad económica y pretenden que su ejercicio en el mercado no sea arbitrario ni desconozca principios constitucionales.

Vistas estas limitaciones al derecho de la libertad económica, habría que preguntarse y de alguna manera, los pactos de no competencia insertos en algunas estipulaciones contractuales de enajenación de establecimientos de comercio y otros negocios de materia puramente comercial vulneran este derecho.

En cuanto a la libertad contractual la jurisprudencia de la corte constitucional(Sentencia de Tutela, 1993$)^{8}$, ha señalado que tiene una doble garantía, en primer lugar que sus limitaciones tengan una base legal y que se justifique socialmente en cuanto se dirijan a garantizar las relaciones justas y libres, y es precisamente sobre esta base entraremos a analizar si las clausulas de no compraventa que se estipulen en compraventas de empresas de establecimiento de comercio, o franquicia, vulneran o no los preceptos constitucionales y los limites

\footnotetext{
${ }^{8}$ Sentencia de Tutela , T-240 (Corte Constitucional de Colombia 1993)
} 
De un primer acercamiento puede establecerse sin demasiada dificultad y bajo un análisis de legalidad "per se", que este tipo de estipulaciones pudieran vulnerar los límites de la libre competencia como principio rector de la actividad económica e incluso el derecho al trabajo, pero la realidad demuestra que no siempre éste tipo de estipulaciones pueden ser contrarias a la competencia, pues en algunas ocasiones se ven justificadas por el beneficio hacia el mercado, protegiendo precisamente la competencia de prácticas desleales de uno de los contratantes y posibilitan de tal manera la realización de estos negocios que sin una garantía de este tipo sería muy difícil llevarlos a cabo.

Según lo expresamos anteriormente, en Colombia la libre competencia económica se concreta en la posibilidad que tiene cualquier persona de participar en determinada actividad económica, con libertad de decidir cuándo entrar y salir de un mercado, sin que exista nadie que pueda imponer, individual o conjuntamente, condiciones en las relaciones de intercambio.

Esto nos lleva a concluir, que la libre competencia tiene dos acepciones, una positiva dada en virtud de la posibilidad que tiene una persona de decidir con plena libertad cuando entrar en el mercado como oferente o demandante sin condicionamientos, y una concepción de la libre competencia en un sentido negativo traducido en la plena libertad que tiene un individuo para salir, abstenerse o retirarse voluntariamente de una actividad empresarial. 
Es perfectamente constitucional, entonces que un individuo voluntariamente decida abstenerse de realizar una actividad y dejar de competir, siendo solamente reprochable esta conducta en la medida que sea presionada, impuesta o se realice con el ánimo de falsear esta competencia, podría llegarse a concluir que es conforme a la libre competencia la decisión voluntaria de un individuo de retirarse de una determinada actividad económica y dejar de ser un competidor en este medio, por lo que no en todos los casos una clausula de no competencia atenta contra este derecho colectivo y por ende tampoco viola el ordenamiento constitucional, por el contrario sustenta el principio constitucional de la libertad contractual permitiendo la realización de operaciones que en otro ámbito no podrían llevarse a cabo.

\section{Validez desde el derecho privado y de la competencia}

El (Codigo Civil Colombiano, 1873), consagró la concepción original de la autonomía de la voluntad privada, como se desprende principalmente de los Arts. 16, en virtud del cual "no podrán derogarse por convenios particulares las leyes en cuya observancia están interesados el orden y las buenas costumbres", y 1602, según el cual "todo contrato legalmente celebrado es una ley para los contratantes, y no puede ser invalidado sino por su consentimiento mutuo o por causas legales". Es precisamente el principio de la autonomía de la Voluntad por el que se dota de eficacia jurídica a las manifestaciones de contractuales de los particulares. La autonomía de la voluntad privada se reconoce por el ordenamiento positivo en Colombia, como una facultad a las personas, para disponer de sus 
intereses con efecto vinculante y por tanto, para crear derechos y obligaciones, para el intercambio de bienes y servicios o el desarrollo de actividades de cooperación, pero que no es absoluta sino que encuentra sus límites en el orden público y las buenas costumbres. Al respecto la Corte Constitucional en (Sentencia Constitucionalidad, 2006) ${ }^{9}$ manifestó que en el ordenamiento jurídico Colombiano, al igual que en muchos otros, la autonomía de la voluntad privada se mantiene como regla general, pero con restricciones o excepciones por causa del interés social o público y el respeto de los derechos fundamentales derivados de la dignidad humana. En virtud de la garantía de la autonomía de la voluntad privada y también, de la garantía de la justicia en ese amplio campo de la actividad de las personas, el ordenamiento positivo Colombiano exige que la manifestación de voluntad sea consciente y libre, esto es, que no esté afectada por irregularidades que genéricamente son denominadas en la ley y en la doctrina vicios del consentimiento, los cuales son error, fuerza y dolo; provenga de persona Capaz y el acto adolezca de objeto o causa ilícita.

La reacción del ordenamiento jurídico frente a los actos contrarios al mismo son las nulidades en el campo del Derecho Privado. Dicha contrariedad proviene de la infracción por los particulares, en ejercicio de la autonomía de la voluntad privada: de normas de carácter imperativo, que tienen interés general; del orden público, que conforme a la doctrina actual tiene un componente tradicional de carácter político y moral, que busca hacer respetar la organización del Estado, la familia y

${ }^{9}$ Sentencia Constitucionalidad, C-996 (Corte Constitucional 29 de noviembre de 2006) 
la moralidad pública, y un componente moderno o reciente de carácter económico y social.

Entonces sería preciso decir que de acuerdo con lo señalado por el derecho civil Colombiano, Las Clausulas de no competencia, tendrían validez cuando sean uso de la facultad que otorga el principio de la autonomía privada y la libertad negocial y no contraríen el orden público o normas de carácter imperativo.

Sin embargo una clausula de no competencia, ve comprometida su validez cuando se adecua a la prohibición respecto de la celebración de acuerdos del Artículo 1 de la (LEY 155 Por la cual se dictan algunas disposiciones sobre prácticas comerciales restrictivas, 1959) que señala: "Quedan prohibidos los acuerdos o convenios que directa o indirectamente tengan por objeto limitar la producción, abastecimiento, distribución o consumo de materias primas, productos, mercancías o servicios nacionales o extranjeros y en general, toda clase de prácticas y procedimientos o sistemas que tiendan a limitar la libre competencia y a mantener o determinar precios inequitativos", pues de un análisis exegético un pacto de no competir claramente tiende a limitar la competencia evita que una persona ingrese al mercado para ofrecer un determinado bien o servicio, y conforme los señala el art 46 del(DECRETO 2153, 1992), se consideraría viciada de objeto ilícito.

Se trata entonces, de una cuestión de derechos afrentados. El problema de análisis pasara a determinar, si desde el punto del Derecho de la Competencia la 
decisión de no realizar una actividad económica como producto de un acuerdo voluntario, pierde o no su validez y en que eventos.

\subsection{Objeto del derecho de la competencia:}

En primer lugar, habría que preguntarse, cuál sería el objetivo o el bien Jurídico hacia el cual se orienta el derecho de las prácticas restrictivas de la competencia, para concluir si una clausula de no competencia en todos los casos tiene o no la potencialidad de vulnerar este bien, pues es precisamente este componente el que matiza el ámbito de aplicación del derecho de las prácticas restrictivas.

En el documento Prácticas Restrictivas de la Competencia en Latinoamérica Y el Caribe los autores (Echeverri Uribe, Díaz Rivera, \& Mick Forero, 2006) señalan que la finalidad del Estado, al aplicar normas sobre la libre competencia, debe ser propender por que el aparato productivo nacional mejore su eficacia, por que las empresas puedan participar libremente en los mercados, y por qué los consumidores encuentren mayor cantidad y variedad de bienes y servicios de mejor calidad a un mejor precio.

En el derecho Norteamericano este criterio ha variado dependiendo de las orientaciones teóricas de la Corte, (Miranda Londoño, Centro de Estudios de la Competencia CEDEC, 1992) en su trabajo Anotaciones Sobre El Derecho Antimonopolístico En Los Estados Unidos De Norteamérica, menciona cómo durante la primera concepción del derecho anti trust Norteamericano, el criterio de análisis carecía de contenido económico, el objeto era proteger a las pequeñas 
Empresas de los efectos nocivos de las grandes, se consideraba a los conglomerados industriales como indeseables sin importar los resultados económicos que produjeren. Hacia la mitad del siglo XX criterio se establece un criterio estructuralista, el cual supone, que el número, tamaño y distribución de las empresas determina el comportamiento y a su vez los resultados que obtiene la industria en su conjunto se observaron con mayor detenimiento los comportamientos de las empresas en mercados oligopólicos y se concluyo que los acuerdos que realizan las empresas de este mercado producen necesariamente efectos anticompetitivos. La Escuela de Chicago plantea el criterio de la eficiencia, bajo el cual las empresas más eficientes podrán reducir su estructura de costos y ofrecer menor precio por sus productos, acaparando una mayor porción del mercado, habrá mayores beneficios para la comunidad en la medida que existan empresas más eficientes que estén en capacidad de ofrecer productos de mejor calidad a precios más bajos aun cuando ello implique mercados altamente concentrados, se plantea entonces que la conducta debe ser declarada legal si trae como consecuencia el beneficio para los consumidores, la legalidad de una conducta se demuestra entonces bajo factores de eficiencia competencia e innovación. Finalmente se formula el criterio de planeación estratégica, bajo el cual se sopesan los conflictos de interés generados con la conducta para determinar su efecto real sobre la competencia. En conclusión este objeto en el derecho norteamericano ha variado pasando de una protección de pequeñas empresas, a la estructura del mercado y ahora al bienestar del consumidor. 
En el derecho Europeo conforme lo señala (Archila, 2001) el objetivo del derecho de la competencia europeo varia, en que este propende tanto por el fortalecimiento de las empresas intercomunitarias como por el beneficio de los consumidores, (Bellamy \& Child, 1992, pág. 38) por su parte señalan que las funciones del derecho de la competencia comunitario son:

1 evitar barreras al comercio derivadas de abuso de posición dominante, acuerdos entre empresas o subsidios estatales

2 preservar la competencia efectiva que permita un mercado único

3 incentivar la eficiencia la innovación y los precios más bajos, estimulando la pequeña y mediana empresa

En Colombia como lo menciona El estudio denominado DERECHO Y POLÍTICA DE LA COMPETENCIA EN COLOMBIA (OECD \& BID, 2009) a partir de la nueva Constitución de 1991 el objetivo de la legislación de competencia en Colombia es precisamente, la protección de la libre competencia económica, que ha sido consagrada como un derecho colectivo (artículo 333). Y así la Corte Constitucional en este sentido en (Sentencia de Constitucionalidad , 1997) ${ }^{10}$ ha manifestado que: "La competencia... a través de las instituciones del mercado, ofrece a la Constitución económica la oportunidad de apoyarse en ellas con miras a propugnar la eficiencia de la economía y el bienestar de los consumidores... el objeto tutelado por la Constitución es el proceso mismo de competencia, con independencia de los competidores, sean éstos grandes o pequeños"

\footnotetext{
${ }^{10}$ Sentencia de Constitucionalidad , C-535 (Corte Constitucional de Colombia 1997)
} 
Objetivo que se encuentra definido en nuestra legislación precisamente por el articulo 2 (Decreto 2153, 1992) modificado por el artículo 3 (Ley 1340,2009 ) en el cual consagra como propósitos de las norma de derecho de la Competencia la libre participación de las empresas en el mercado, el bienestar de los consumidores y la eficiencia económica.

Colombia acoge diversas teorías de las ya esbozadas, recoge los postulados de la escuela de Chicago en cuanto a la eficiencia económica y el bienestar del consumidor y un enfoque Europeo en cuanto a la protección de la pequeña y mediana empresa garantizando el acceso libre al mercado (Archila, 2001).

Concluyendo, el objeto y fin del derecho de la competencia en Colombia está dado por el bienestar del consumidor, la eficacia económica, la innovación, la equidad, la estructura de industria competitiva, el crecimiento y la protección de pequeñas y medianas empresas. Objetivos y fines que no siempre se lesionan con la estipulación de clausulas de no competencia, por el contrario las mismas constituyen instrumentos valiosos y necesarios para evitar competencia desleal o garantizar la real adquisición y dominio de bienes inmateriales como el KnowHow - la clientela, la adquisición, transferencia y comercialización de nuevas tecnologías, o para permitir la realización de negocios y formas contractuales que permitan al mercado y a sus empresas ser más eficientes. 


\subsection{Prácticas restrictivas de la Competencia}

El problema de una clausula de no competencia, radica en que por sí sola puede encajar en las prohibiciones que traen las normas sobre prácticas restrictivas de la competencia. Como El apartado 1 del artículo 81 (Tratado Constitutivo de la Comunidad Europea, 1992) o la La sección 1 de (Sherman Antitrust Act, 1890) que señala "Every contract, combination in the form of trust or other wise, or conspiracy, in restraint of trade or commerce among the several States, or with foreign nations, is declared to be illegal." , y por supuesto el artículo 1 de la ley 155 de 1959 de Colombia Artículo 1‥ Modificado: Artículo 1 Decreto 3307 de 1963. La cual prohíbe los acuerdos o convenios que directa o indirectamente tengan por objeto limitar la producción, abastecimiento, distribución o consumo de materias primas, productos, mercancías o servicios nacionales o extranjeros y, en general, toda clase de prácticas, procedimientos o sistemas tendientes a limitar la libre competencia y a mantener o determinar precios inequitativos.

Estas prohibiciones, están redactadas de manera tan general, que involucran un gran número de actuaciones, que eventualmente pueden causar efectos favorables o pro competitivos, y una interpretación literal resulta excesiva, si tenemos en cuenta que las limitaciones que puede oponer el derecho de la competencia a la libertad contractual deben estar sustentadas en garantizar las relaciones justas y la protección de ese bien jurídico, las cuales materialmente no se ven amenazadas, afectadas y por el contrario son favorables, garantizan la eficiencia del mercado o benefician al consumidor, entonces tal como lo sostiene 
(Águila-Real, 2004, pág. 4) las restricciones a la competencia que sirven a fines contractuales -reducción de los costes de transacción- y en el marco de transacciones legítimas no pueden considerarse genéricamente prohibidas.

El derecho de la competencia no puede verse como una regulación de la libertad contractual, sino como una forma de "corregir externalidades", es decir, de asegurar que los pactos entre competidores no causan daño a los consumidores en forma de restricciones apreciables de la oferta o de la calidad y aumentos de precios (Meese, 2003, pág. 88). De allí la necesidad de matizar la aplicación de reglas per se, en pro de la libertad contractual y la misma competencia como a continuación expondremos.

\subsection{Tratamiento en el derecho comparado}

Para observar los criterios de análisis de este tipo de estipulaciones, por ser nuestra legislación orientada por los desarrollos norteamericanos del derecho antitrust, empezaremos por mencionar que, El Juez Stevens en el caso (National Society of Professional Engineers vs United States, 1978) ${ }^{11}$ precisó que en el ordenamiento jurídico Estadounidense, existen dos sistemas de análisis de las practicas antimonopolísticas que las cortes pueden aplicar la "Regla Per Se" y la "Regla de la Razón" . la primera de ellas se utiliza para analizar todos aquellas practicas cuyos efectos resultan tan evidentemente anti competitivos, que no se necesita realizar un juicio para concluir que son ilegales. La regla constituye una

\footnotetext{
${ }^{11}$ National Society of Professional Engineers vs United States, 435 us 679 (Supreme Court USA 1978)
} 
presunción de derecho de la ilegalidad de una determinada conducta, que debe ser sancionada sin que para ello deba analizarse o entrar a probarse los beneficios que al mercado pueda conllevar una determinada restricción y en consecuencia la corte no escuchará los argumentos del demandado, un ejemplo de esta regla se puede apreciar en el caso (Arizona vs Maricopa County Medical Society, 1982$)^{12}$ en el cual la Corte condenó a la sociedad por establecer un acuerdo entre sus asociados para fijación de precios máximos, aplicando la regla per se a pesar de que el acuerdo tenía por objeto la reducción de los precios a los consumidores. Como lo señala la (UNCTAD, 2004, pág. 62) esta se aplica generalmente a aquellas actividades, estrategias o alianzas que sin lugar a dudas son susceptibles de aparejar una consecuencia anticompetitiva en el mercado, impide que los implicados presente justificaciones de efectos pro competitivos de su conducta y es por ello que la tendencia es a reducir cada vez más su ámbito de aplicación a lo que se conocen como restricciones explicitas o desnudas.

El mayor atractivo de las prohibiciones per se para, los ordenamientos jurídicos, es su relativo bajo costo de monitoreo. Ésta prohibición ha sido establecida por razones de economía procesal, o eficacia administrativa, en ella el organismo de competencia no está en la necesidad de soportar la carga de la prueba sobre los efectos restrictivos de dichos acuerdos, pues tales no son objeto de análisis o verificación y en consecuencia su aplicación se aparta de la eficiencia económica.

${ }^{12}$ Arizona vs Maricopa County Medical Society , 457 u.s. 332 (Supreme Court USA 1982). 
Una prohibición per se, no puede apartarse del efecto económico y por ello coincidimos en lo señalado por Naciones Unidas en su Manual para La Formulación y Aplicación de las Leyes de Competencia, en que, no debería llegarse a la conclusión, que la parte que incurre en ellas no pueda demostrar sus efectos positivos, si los hubiere, llegado el caso, pues lo que supone es una inversión de la carga probatoria y no una absoluta imposibilidad de comprobación en sentido contrario. Este hecho, sin embargo, frecuentemente pasa por alto entre los hacedores de políticas de competencia, que tienden a concluir en la imposibilidad de refutar una presunción de efectos contrarios a la competencia, argumentando erradamente el carácter per se de la prohibición establecida, como lo veremos en el caso Colombiano más adelante.

En cuanto a la regla de la razón se dota al análisis de la conducta de un componente económico de eficiencia, pues se ha entendido que existe una gran variedad de actuaciones mercantiles, que aun cuando pudieren ser subsumidas en las prohibiciones la competencia, son beneficiosas para el mercado o el consumidor y por tanto, ser legales. A diferencia de la regla per se, aquí es posible probar el efecto benéfico para la eficiencia industrial o los consumidores y de esta manera permitir su realización y efectos. Según lo señala (Flint Blanck, 2002, pág. 616) la regla de la razón permite sopesar factores competitivos y determinar si la restricción es razonable o no y si existe una interferencia significativa o impacto de importancia en la competencia, la legalidad o no de la conducta estará basada en si ésta, promueve, restringe o destruye la competencia. Esta teoría señala que 
algunas prácticas pueden promover la competencia y perfeccionar los mercados por lo cual La corte Norteamericana ha introducido en el análisis el papel de la eficiencia e integración de la capacidad productiva.

En el caso (Standard Oil Co of New Jersey vs United States, 1910) ${ }^{13}$ la Corte Suprema Norteamericana se cuestiona sobre el alcance de la interpretación literal de la sección 1 de la ley Sherman, y señalaba que ésta podría llegar a contener un gran número de contratos o acuerdos que no necesariamente dañan al público, atentan o afectan la competencia, para concluir que un acuerdo o contrato solo atenta contra la ley Sherman, cuando implica una restricción indebida a la competencia, que no puede ser razonable, pues un sentido más amplio violaría la libertad contractual. Al aplicar la regla de la razón a una situación determinada se deben analizar 3 aspectos esenciales: La naturaleza, el propósito y el efecto de la restricción a la libre competencia (Miranda Londoño, El regimen General de la libre Competencia, 1999) La legalidad de la conducta se analiza, teniendo en cuenta la historia de la restricción, los hechos particulares del negocio y las razones por las cuales fue impuesta.

De esta manera la regla de interpretación basada en la razón, permitió limitar la aplicación del artículo 1 de la Sherman Act, y permitió a la corte determinar que algunos contratos que podrían ser subsumidos por la sección primera de esta norma, no son ilegales (Miranda Londoño, Centro de Estudios de la Competencia

\footnotetext{
${ }^{13}$ Standard Oil Co of New Jersey vs United States, 221 u.s. 1 (Supreme Court USA 1910)
} 
CEDEC, 1992) entre los cuales están: Las restricciones accesorias y Las restricciones razonables.

En 1898 el juez William Howard Taft's de la UnitedStatesCourt of Appeals fortheSixthCircuit, planteó la llamada doctrina de las restricciones accesorias(Addyston Pipe and Steel Co. v. United States, , 1898) ${ }^{14}$ en el cual se empieza a afirmar que una clausula inhibitoria de la competencia era legal cuando era accesoria en relación al objeto principal del contrato que es en sí mismo legal y fuere necesaria para garantizar al acreedor el disfrute de los frutos legítimos del contrato o para protegerlos contra un uso injusto de esos frutos por la otra parte.

Las restricciones accesorias o parciales al comercio, dentro de las cuales se encuentran las clausulas inhibitorias de la competencia, son legales cuando resultan razonablemente necesarias para el propósito principal del contrato o cuando la restricción resulta razonable comparada con el beneficio que obtiene el público en general (Miranda Londoño, Centro de Estudios de la Competencia CEDEC, 1992)

Según la jurisprudencia Norteamericana, esta doctrina resulta aplicable si se dan cuatro presupuestos a saber: que se restrinja la libertad de competir; que la restricción sea accesoria, subordinada y necesaria; que la restricción sea proporcionada o razonable y finalmente que el acuerdo principal sea pro competitivo.

${ }^{14}$ Addyston Pipe and Steel Co. v. United States, 85 F. 271 United States Court of Appeals for the Sixth Circuit 1898 
En Europa la teoría de las restricciones accesorias fue acogida a mediados del siglo pasado (Miranda Serrano L. M., 1994, pág. 484) como una manera de matizar precisamente esos acuerdos jurídicamente inherentes y necesarios para su celebración y que contravenían el articulo 81.1 TCE (Martí Miravalls, 2007, pág. 63), y en consecuencia, cuando los aspectos esenciales de un contrato no tengan por objeto o efecto de restringir la competencia no se aplicara la prohibición a las restricciones accesorias directamente relacionadas con la realización de la operación (Zurimendi Isla, 2003, pág. 124)

La legislación europea (Comunicación de la Comisión , 2008) acoge también la teoría de las restricciones accesorias, entendiéndolas como cualquier restricción de la competencia que esté directamente relacionada con la realización de una operación principal no restrictiva y sea necesaria y proporcionada a la misma. Y en este caso escapa a la aplicación del apartado 1 del artículo 81 (Tratado Constitutivo de la Comunidad Europea, 1992)

Entonces las restricciones accesorias de la competencia son necesarias para poder organizar la producción conjunta de bienes o servicios o la integración económica. La cooperación se articula entonces a través de una gran variedad de contratos que tienen efectos restrictivos de la competencia pero que se consideran fuera de la prohibición, tales como sociedades, relaciones laborales, fusiones, franquicias, acuerdos de distribución, acuerdos de producción o distribución conjunta, la creación conjunta de instalaciones o infraestructuras necesarias para que pueda desarrollarse una actividad económica como los mercados o las bolsas 
(Arthur, 2000, pág. 337) por lo cual Todos los intercambios voluntarios crean riqueza y las restricciones que facilitan o eliminan obstáculos a la realización de intercambios voluntarios deben considerarse como ancillary restraints

\subsection{Tratamiento en el derecho Colombiano}

La ley Colombiana no se refiere explícitamente a los criterios de ilegalidad per se y de rule of reason (regla de razón). Existe cierta controversia entre los profesionales del país sobre este punto, ya que estos conceptos no se adaptan adecuadamente al régimen de responsabilidad administrativa de la ley Colombiana. Una interpretación mantiene que la regla de ilegalidad per se equivale a una presunción de ilegalidad de derecho y sólo se aplica a los acuerdos y los contratos y conductas descritos explícitamente en los artículos 47 y 48 del decreto 2153 de 1992. Por el contrario, la regla de razón, al actuar como una evaluación que mide los efectos a favor y en contra de la competencia, sería de aplicación en los demás casos en los que los efectos económicamente dañinos de la conducta debieran demostrarse (OECD \& BID, 2009)

El profesor (Uribe, 2006, pág. 166) sostiene que la Superintendencia de Industria y Comercio de Colombia, trabaja para los casos que tienen como objeto o como efecto restringir la competencia la ilegalidad "per se" pues lo asemeja a una presunción de derecho. Conforme a la interpretación que ha hecho la SIC y la 
doctrina colombiana, sobre las conductas señaladas en los artículos 47 y48 del Decreto 2153/92, pueden ser sancionados tanto por su objeto como por sus efectos y La única defensa válida de los acusados en este caso sería demostrar que no se incurrió en la conducta imputada. En otras palabras tales actos son ilegales per se.

Las clausulas de no competencia pueden quedar adecuadas en la conducta descrita en el numeral 8 del articulo 47 del decreto 2153 de 1992 pues llegarían a tener por objeto o como efecto abstenerse de producir un bien o servicio o afectar sus niveles de producción" con lo cual ha hecho carrera la posición doctrinal según la cual, cualquier clausula de no competencia es nula "per se" sin importar sus efectos pro competitivos pues puede enmarcarse dentro de la prohibición del articulo 47 -8 del decreto 2153 de 1996, siendo siempre analizadas bajo una perspectiva de responsabilidad objetiva en la cual a juicio de la Superintendencia de Industria y Comercio, solo basta con que tenga lugar el acuerdo, para considerar que son contrarios a la libre competencia y por ende su objeto ilícito.

La Superintendencia de Industria y Comercio de Colombia, en (Concepto , $2000)^{15}$, por el cual soluciona una consulta sobre la viabilidad de establecer una cláusula mediante la cual los accionistas de una sociedad en proceso de enajenación, se comprometen a no realizar durante un tiempo determinado actividades relacionadas con el objeto social de la empresa enajenada sosteniendo que :

${ }^{15}$ Concepto , 58216 (Superintendencia de Industria y Comercio de Colombia 12 de septiembre de 2000) 
- Aún cuando se ha reconocido cierto margen de libertad a los particulares para que ajusten el sentido de los negocios a sus propias expectativas e intereses -autonomía privada de la voluntad-, tal libertad no es plena pues forzosamente habrá de sujetarse, entre otros aspectos, al sistema jurídico y social imperante; siendo así como el orden público constituye un lindero a la libertad contractual que poseen los intervinientes en el tráfico jurídico, de suerte tal que sus acuerdos y convenios habrán de realizarse dentro los términos precisos que defina la misma ley, y sin incurrir en ninguna de las prohibiciones que hayan sido establecidas.

Bajo esta perspectiva ha de tenerse en cuenta que, ante la necesidad de garantizar el sistema de competencia económica se han proscrito aquellas conductas que afecten o restrinjan su libre ejercicio. Así, el decreto 2153 de 1992 contiene un listado enunciativo de acuerdos considerados como atentatorios de la libre competencia, entre los que cobran especial interés para el caso que ocupa nuestra atención, los "...que tengan por objeto o como efecto abstenerse de producir un bien o servicio o afectar sus niveles de producción".

Por lo cual, todo acuerdo a través del cual se pretenda la exclusión, actual o futura, de un competidor en el mercado respectivo, se considerará como ilícito en cuanto su objeto mismo estaría padeciendo de tal afectación. Con todo, es preciso advertir que ésta, como las demás conductas restrictivas de la competencia, supone un carácter objetivo, de tal suerte que para su configuración no es preciso establecer y menos demostrar, que el autor de la conducta tuvo la intención o el propósito de restringir la libre competencia pues basta con que haya tenido lugar el acuerdo en los términos indicados para que por sí solo se torne en restrictivo.

La inclusión de una cláusula en un contrato de compraventa por virtud de la cual los accionistas de la empresa enajenada se comprometen a no realizar, directa o indirectamente, por un tiempo determinado actividades relacionados con el objeto social de la empresa transferida, constituiría un acuerdo contrario a la libre competencia. Lo anterior 
en razón a que el comportamiento descrito supondría una concertación de voluntades cuyo objeto o efecto sería abstenerse de producir un determinado bien o servicio.

No es dable argumentar que tal acto sería lícito por tratarse del ejercicio de una libertad de índole constitucional, y que justamente por ello constituye un desarrollo de la libertad de empresa del individuo, toda vez que como se indicó, este derecho lejos de ser absoluto se encuentra sometido a los límites que el legislador señale. En este caso particular, la restricción a la cual se encuentra sometida, es a las normas que el legislador extraordinario expidió como desarrollo del derecho a la libre competencia. " .

En igual sentido en laudo producido en proceso Arbitral celebrado en la Cámara de Comercio de Bogotá (Cementos Hércules S.A vs Cementos Andino S.A, 2000), en el cual se considero la nulidad de una clausula establecida en un contrato de venta de activos, que establecia la obligacion para el comprador de dejar de vender un tipo de cemento en un area geografica y durante un tiempo determinados.

Esta primera y escasa posición de la Doctrina Colombiana, refleja que el análisis de las clausulas de no competencia, se hacía teniéndose en sí misma como una clausula restrictiva absoluta, que desde el modelo del derecho de la competencia Norteamericano se entiende anticompetitiva per se, y sin importar la manera en que se construya este tipo de clausulas ni el efecto producido en el mercado, siempre tendrán visos de nulidad. Criterio que resultaba a todas luces excesivo, pues de esta manera se está limitando y restringiendo el derecho a la libertad negocial, impide el surgimiento y realización de otras formas y garantías contractuales y eventualmente puede lograr desestimular la celebración de ciertos 
contratos con efectos contrarios a los pretendidos por la ley, pues no en todos los casos con el uso de este tipo de estipulaciones se atenta realmente contra la competencia o lesiona derechos o principios constitucionales, sino que por el contrario la protegen al estimular la celebración de un negocio que en otras circunstancias no podría darse o se daría de manera más gravosa.

Esta posición doctrinal que suponía un tratamiento "per se " a los acuerdos restrictivos señalados en el artículo 47 del decreto 2153, y que defendió y aceptó gran parte de la doctrina. Desde hace unos años tiende a variar, pues inclusive acuerdos que siempre fueron considerados ilegales per se como los acuerdos horizontales de fijación de precios (Ibarra \& Miranda, 2000, pág. 4), tienden a ser analizados por las cortes hoy en día bajo la regla de la razón. fue precisamente el Tribunal Administrativo de Cundinamarca (Sentencia , 2003) ${ }^{16}$ por la cual se resuelve la nulidad y restablecimiento del derecho iniciado por demanda que formulara la Asociación Nacional de Entidades de Seguridad Privada - ANDEVIP contra la Superintendencia de Industria y Comercio, con el fin de que se anulen los actos administrativos por medio de los cuales dicha autoridad declaró la existencia de un acuerdo anticompetitivo de fijación horizontal de precios y le impuso sanciones pecuniarias bajo el argumento que solo basta con que tenga lugar el acuerdo directo o indirecto de fijación de precios para considerar que son contrarios a la libre competencia. Para el Tribunal no es posible sostener como hasta el momento lo había hecho la Superintendencia de Industria y Comercio de

\footnotetext{
${ }^{16}$ Sentencia , 2001-264 (Tribunal Administrativo de Cundinamarca 27 de noviembre de 2003).
} 
Colombia, que los acuerdos descritos en los artículos 47 y 48 del decreto 2153 de 1992 tengan un tipo de responsabilidad objetiva o regla per se, que baste solamente de acreditar su existencia para declarar su nulidad, sino que se tratan de presunciones de ilegalidad, que pueden desvirtuarse demostrando que en el mercado existe libertad de entrada, libertad de escogencia, variedad de precios y servicios , así como una eficiencia en el aparato productivo. Bajo esta premisa se acepta entonces en el ordenamiento jurídico la posibilidad que existan acuerdos que se enmarquen en las prohibiciones del decreto en las que no se presente el ingrediente restrictivo de la competencia.

Esta posición jurisprudencial que aun no ha tenido decisión definitiva por el Consejo de Estado, tiene mayor fundamento cuando nuestro ordenamiento jurídico comercial consagra normas que implican obligaciones de no competencia justificada por la protección de otros intereses legítimos, como es el caso del artículo 296 que en el numeral 3 y 4 (Codigo de Comercio Colombiano decreto ley $410,1971)$, norma que claramente está limitando la posibilidad del socio colectivo de formar parte de empresas de la competencia o iniciar su propia actividad emprendedora sin contar con el voto favorable de los demás socios, igualmente la (ley 222,1995$)$ en su artículo 23 numeral 7 en cuanto a los deberes de los administradores restringió la posibilidad de realizar actos de competencia con las empresas que gestionan, y el Art 1318,1319 del (Codigo de Comercio Colombiano decreto ley 410, 1971), permite igualmente, que en el contrato de agencia comercial pueda pactarse la prohibición para el empresario de de servirse de 
varios agentes en una misma zona y para el mismo ramo de actividades o productos, así mismo se puede pactar prohibición para el agente de promover o explotar en la misma zona y en el mismo ramo, los negocios de dos o más empresarios competidores.

En la doctrina Colombiana se ha reconocido por algunos autores como el doctor (Arrubla Paucar, Contratos Mercantiles Tomo II, 2003, págs. 251,309) quien señala que la inhibición de competencia es necesaria y surge como obligación en contratos de concesión y de colaboración empresarial, considera a manera de ejemplo que al concedente no le es dable hacer competencia con el propio concesionario en la zona que ha sido señalada para la concesión, si esto fuere posible habría una competencia desigual, pues el concedente tiene mejores descuentos que los del concesionario, obteniendo mejores rendimientos económicos y aprovechándose del mercado que ha venido siendo mantenido y aumentado por este concesionario. El doctor (Ravassa Moreno, 2001, pág. 291) consideró que en la enajenación de establecimientos de comercio surge una particular obligación de no hacer para el vendedor, que consiste en no hacer competencia al comprador, llevándose la clientela del establecimiento de comercio. También considero valido pactar este tipo de clausulas en contratos de franquicia (Velilla, 2002, pág. 311) para evitar que el franquiciado ingrese en negocios competitivos durante el termino de la franquicia y después de cierto periodo posterior a su finalización. 
Finalmente La superintendencia de Industria y Comercio mediante (Resolucion , 2010) ${ }^{17}$ acogiendo la doctrina Norteamericana y Europea de las restricciones accesorias, reconoce la posibilidad de pactar clausulas de no competencias en ciertos contratos cuando pretendan asegurar el cumplimiento de la obligación principal.

... Análisis similar tendría que hacerse en el caso de las cláusulas de no competencia, pues en el caso de los contratos de venta o cesión de activos estas restricciones se encuentran directamente vinculadas, entre otros, a la protección que debe darse al comprador frente a la competencia del vendedor para obtener el valor de los activos transferidos, que le permita fidelizar la clientela y asimilar y explotar los conocimientos técnicos. Las cláusulas inhibitorias de la competencia garantizan la cesión al comprador del valor íntegro de los activos transferidos, que, por lo general, comprende tanto activos materiales como inmateriales y los conocimientos técnicos desarrollados por el vendedor.

Es por ello, que las cláusulas que no tengan la capacidad de obstruir o impedir la entrada de otros competidores al mercado, son lícitas y por el contrario, a través de las mismas el comprador tiene la posibilidad de aprovechar las ventajas que le proporciona la garantía de que podrá obtener el valor íntegro de la empresa adquirida de acuerdo con lo razonablemente necesario para lograr dicho objetivo.

Sin embargo, una cláusula o un contrato que impida a un comerciante competir, podría considerarse en abstracto, restrictivo de la competencia, pues a pesar de haber transferido unos activos, el vendedor, siempre tendría la posibilidad de iniciar una nueva empresa, situación que favorecería en últimas al consumidor que contaría con una oferta adicional ...De esta suerte, debe tenerse en cuenta que las cláusulas inhibitorias de la competencia están justificadas sólo con el objeto de hacer posible la operación, cuando su duración, su

\footnotetext{
${ }^{17}$ Resolucion , 46325 (Superintendencia de Industria y Comercio 31 de agosto de 2010)
} 
ámbito geográfico de aplicación, su contenido y las personas sujetas a ellas no van más allá de lo razonablemente necesario para lograr dicho objetivo.

No obstante lo anterior, el alcance de las mencionadas cláusulas no podrá considerarse prima facie restrictivo de la competencia, pues para llegar a tal conclusión se deberá partir de un análisis del contexto que rodea a las mismas, el cual resultará ser tan importante como su contenido a la hora de evaluar el efecto anticompetitivo que puedan tener en el mercado. Así pues, deberán tenerse en cuenta, entre otros, los siguientes factores: (i) el tamaño del mercado relevante; (ii) el número de oferentes; (iii) la participación que cada una de las partes involucradas tienen en el mercado, con el fin de establecer si con las estipulaciones pactadas se vulnera el interés económico general."

Podemos llegar sin lugar a dudas a concluir que en el derecho de la competencia Colombiano, se ha modificado a mi juicio acertadamente el criterio de asumir las clausulas de no competencia como ilegales per se y acoger el criterio Europeo para el análisis de estos pactos, como restricciones accesorias, aclarando el camino para que en ejercicio de su autonomía contractual las partes puedan estipular clausulas de no competencia, siempre y cuando sean accesorias necesarias, proporcionadas y razonables.

\subsection{Tratamiento en la Comunidad Andina:}

La (DECISIÓN 285 C A, 1991) de la Comunidad Andina, por la que se pretende prevenir o corregir las distorsiones en la competencia generadas por prácticas restrictivas de la libre competencia en sus países miembros, señaló en el artículo tercero, que se entiende por prácticas restrictivas de la libre competencia los acuerdos, actuaciones paralelas o prácticas concertadas entre empresas que 
produzcan o puedan producir el efecto de restringir, impedir o falsear la competencia. Y en el artículo 4 literal d Se consideran acuerdos, actuaciones paralelas o prácticas concertadas: La subordinación de la celebración de contratos a la aceptación de prestaciones suplementarias que, por su naturaleza o con arreglo a la costumbre mercantil, no guarden relación con el objeto de tales contratos.

Como se percibe de la norma transcrita y se ha criticado por algunos autores entre otros (Miranda Londoño, Centro de Estudios de la Competencia CEDEC, 1992) la decisión comunitaria no trae prohibiciones per se, las cuales desecha totalmente y en consecuencia solamente considera contrarias a libre competencia aquellos acuerdos que puedan llegar o produzcan efectos nocivos en el mercado. Lo cual abre la posibilidad de pactar clausulas de no competencia siempre y cuando tengan un carácter accesorio y necesario que garantice el cumplimiento de un contrato no restrictivo y con las mismas no se produzcan o puedan producir el efecto de restringir, impedir o falsear la competencia.

\section{Requisitos para la validez}

Con el avance significativo que ha dado la Superintendencia de Industria y Comercio de Colombia en (Resolucion , 2010) ${ }^{18}$ al considerar que este tipo de acuerdos en el marco de una fusión o adquisición no son prima facie restrictivos, para aceptar su estudio de legalidad bajo los presupuestos que expondremos a continuación, y con la aclaración que dados los diferentes matices y contratos

\footnotetext{
${ }^{18}$ Resolucion , 46325 (Superintendencia de Industria y Comercio 31 de agosto de 2010)
} 
dentro de los cuales pueden suscribirse este tipo de clausulas es necesario evaluar cada caso el contexto y el efecto pro o anticompetitivo que puedan tener en el mercado, a fin de establecer si con las estipulaciones pactadas se vulnera el interés económico general.

Pasaremos entonces a determinar aquellos requisitos que debe reunir una clausula de no competencia para ser válidamente pactada dentro del ordenamiento jurídico Colombiano, para lo cual tomaremos como base la jurisprudencia y legislación Europea al ser la que sirvió de soporte a la SIC para la resolución que acoge la posibilidad de pactar Clausulas accesorias de no competencia citada anteriormente.

\section{1 La Clausula inhibitoria de la competencia debe ser Accesoria y}

Subordinada:

Una pacto de no competencia puede tener un carácter principal o accesorio. Entendiéndose por principal aquel acuerdo que tiene como objeto la no competencia y accesorio aquel que sirve para garantizar el cumplimiento de otro tipo de obligaciones contractuales consideradas principales.

Es aquí donde encontramos la primera limitante a su legalidad, la doctrina ha aceptado que los pactos de no competir desnudos o desprovistos de un propósito o justificación carecen de una razonabilidad, y son considerados ilegales per se. (Farnsworth, 1990, pág. 357) al igual que el juez Taft, opinan que ese tipo de promesas de no competir constituyen un tipo de esas restricciones no razonables 
per se. Para que una cláusula de no competir no sea una restricción indebida del comercio debe satisfacer ciertos requisitos y el primero de ellos es que la obligación de no competir sea parte de un contrato que en sí mismo no sea restrictivo. No interesa si la inhibición de la competencia está pactada dentro del contrato 0 en documento independiente pero en este segundo evento debe recordarse que necesariamente debe derivar su existencia de una relación contractual no restrictiva ya que la pura obligación de no competir independiente de cualquier otro negocio, se considera que es una restricción indebida.(Adame Goddard, 2001, pág. 714). Además de ser accesorias deben ser subordinadas dependientes, estar vinculadas íntimamente al objeto principal, desde el punto de vista jurídico económico, y su único fin será entonces permitir la celebración del contrato que en su defecto no se efectuaría o se haría en condiciones más onerosas.

(Miranda Serrano, 2000, pág. 13) Sostiene que una restricción está directamente relacionada con la operación principal cuando está subordinada a su realización e indisolublemente ligada a la misma. Entre la operación principal y la restricción debe existir un vínculo sustancial y no meramente incidental, de modo que aunque la restricción sea separable de la prestación principal, su fin no es otro que contribuir a posibilitar su realización.

En conclusión las restricciones principales, desnudas o carácter general al comercio, son ilegales per se, en consecuencia una clausula inhibitoria de la competencia para que no sea considerada prima facie ilegal por objeto ilícito, debe 
ser accesoria y estar directamente relacionada con la realización de una operación principal no restrictiva lo cual le permitirá ser analizada su razonabilidad.

\section{2 La Clausula Inhibitoria de la Competencia debe ser Necesaria:}

No basta que una clausula de no competencia sea un pacto accesorio y subordinado sino que además para su validez, ha de ser Necesaria para la realización del contrato, lo que hará suponer que esta clausula de no competencia determina en alta medida la posibilidad de haber llevado a efecto la operación, pues en ausencia de la misma no se hubiere celebrado o se haría en condiciones más inciertas, con costos más altos, en mayor tiempo o dificultad. Si a partir de factores objetivos puede concluirse que la restricción, la principal operación no restrictiva resultaría de difícil o imposible realización la clausula de no competencia podría considerarse necesaria. (Miranda Serrano, 2000, pág. 13), y para determinar si una restricción es económicamente imprescindible en la perfección del acuerdo principal, no debemos atender a apreciaciones o circunstancias subjetivas de las partes, sino a factores objetivos que hacen concluir que nadie en esas circunstancias hubiera realizado una operación idéntica sin la restricción. (Kjolbye, 2004, pág. 569)

Un ejemplo de ello puede verse en la (Decision , 1990) ${ }^{19}$ Elopak/Metal Box - Odin de la Comisión Europea, quien al analizar un acuerdo entre Elopak y Metal Box para la constitución de Odín empresa que desarrolla tecnologías conjuntas y que

\footnotetext{
${ }^{19}$ Decision , 90/410 (Comision Europea 13 de julio de 1990)
} 
contenía unas clausulas restrictivas para el uso de conocimientos técnicos KnowHow y de venta de acciones, concluye que "Las disposiciones relativas a la utilización por parte de Odin de los conocimientos técnicos sujetos a derechos de propiedad industrial («know-how ») propiedad de las partes y su obligación de mantenerlos en secreto son necesarias para evitar comprometer los objetivos y las existencias de Odin y debilitar sus objetivos y su existencia. Son consecuencia necesaria del deseo de las partes de limitar la cooperación a un ámbito específico y reflejo del legítimo objetivo de mantener en secreto los conocimientos técnicos (« know-how »). Por consiguiente, las disposiciones relativas a las actividades de Odin no entran dentro del ámbito de aplicación del apartado 1 del artículo 85

La necesidad de la existencia de pactos qué inhiban la competencia, se ha aceptado de manera generalizada básicamente como mecanismo que protege la transferencia de activos intangibles como conocimientos técnicos conocidos como Know how, la clientela cedida y la fama comercial o expectativa de negocio, siendo este primero la piedra angular de la protección aceptándose de manera generalizada incluir cláusulas apropiadas para asegurar la protección del knowhow, tanto durante la vigencia del contrato como para después de su terminación (Aguilar Álvarez de Alba, 2000, pág. 92), que pueden consistir en no hacer uso del know-how que ha adquirido para dedicarse a una actividad mercantil, que compita con la del propietario de los secretos.

El know how se usa según (Turner, 1962, pág. 17) para abarcar procesos complicados y definidos, así como la habilidad adquirida y la experiencia 
acumulada por un técnico que son inseparables de él constituyendo su valor. (Van Notten, 1963, pág. 526;527) señala que el Know How designa los procedimientos prácticos industriales y comerciales que no pueden ser descritos con precisión, los que derivan su valor como consecuencia de un determinado grado de novedad y secreto, (Creed \& Bangs, 1960, pág. 93) lo definen como un conjunto de invenciones procesos, formulas o diseños no patentados o no patentables, que incluyen experiencia y habilidad técnica acumulada, la que puede ser transmitida preferente o exclusivamente, a través de servicios personales. La clientela cedida siendo otro de los grandes elementos de protección a través del la inhibiciones de competencia, siempre ha tenido un polémico tratamiento como tema de análisis por parte de los doctrina quienes en su mayoría sostienen que la misma no se trata de de un bien objeto de transferencia y que mucho menos pueda hablarse de un derecho de propiedad sobre la misma (Goldschmidt, Rodríguez, \& Ruiz, 2008, pág. 171) , sin embargo es innegable su valor y debemos entenderla como ese conjunto de relaciones de hecho que existen con los clientes y que aumentan significativamente el valor de una empresa, se trata de una corriente de relaciones que surge como consecuencia de la interacción de la hacienda sobre el medio y de este sobre aquella, y los vínculos jurídicos se traban porque hay un conjunto de personas con necesidades y una hacienda dispuesta a colmarlas, de suerte que la clientela se forja como resultado de la actividad de la hacienda y de factores exteriores a ella (De Sola Cañizares, 1962, pág. 178), concepto en el que finalmente podemos incluir no solo los compradores habituales sino también la aptitud o cualidad del establecimiento para atraer o conservar la clientela 
(Guyenot, 1975, pág. 312) junto a la expectativa razonable de ventas futuras "valor llave“ (Martinez Medrano, 2006, pág. 7), derechos a nuestro juicio transferibles y que van unidos siempre al establecimiento comercial. Finalmente la fama comercial o como señala el profesor (Garrigues, 1974, pág. 194) las expectativas, es decir la esperanza de obtener en lo sucesivo ciertos beneficios por la mejor organización de la empresa, por la eliminación de la concurrencia y otras circunstancias que determinan una mayor o menor certidumbre en la venta de los productos o el suministro de los servicios.

En protección a dichos activos, inmateriales la legislación y la doctrina Europea, han señalado que las clausulas de no competencia, que son impuestas al vendedor en la enajenación de toda o parte de una empresa, establecimiento o fondo de comercio, garantizan la cesión al comprador del valor íntegro de los activos transferidos, que, por lo general, comprende tanto activos materiales como inmateriales, como el fondo de comercio y los conocimientos técnicos desarrollados por el vendedor. Estas cláusulas no sólo están directamente vinculadas a la concentración, sino que también son necesarias para su realización, porque hay buenos motivos para creer que sin ellas no sería posible la venta de la totalidad de la empresa o de parte de la misma (Comunicación de la Comisión sobre las restricciones directamente vinculadas a la realización de una concentración y necesarias a tal fin C56/03, 2005).

También son consideradas necesarias las restricciones accesorias que se plasmen en contratos de colaboración empresarial como por ejemplo la 
Franquicia y el joint venture, (La Pera, 1974, pág. 79) sostiene que los colaboradores se deben entre si la más estricta lealtad en cuanto al negocio para el cual se han vinculado, apareciendo de esta manera un deber de no concurrencia respecto al partnership. En el contrato de franquicia las clausulas de no competencia son consideradas necesarias para su correcta ejecución en cuanto se entiende que protegen y tutelan los derechos de la propiedad industrial la uniformidad y la reputación del sistema de franquicias (Martí Miravalls J. , 2008, pág. 53). En general estas clausulas tienen usos en aquellos contratos que impliquen licenciamiento de y transferencia de tecnología, en los que no es raro que el licenciante o viceversa se abstengan de competir en determinada rama productiva (Cavanellas de las Cuevas, 1994, pág. 504) siendo la inhibición de la competencia una de las restricciones más frecuentes (Ortiz Blanco, 2005, pág. 95)

Existen doctrinantes que hoy critican el criterio de necesidad para reemplazarlo en aras de de la libertad contractual por el de un criterio más dúctil como la utilidad, de modo que debería ser considerada restricción accesoria cualquier pacto útil aunque no sea necesario para la finalidad perseguida por las partes en el contrato so pena de quebrantar la libertad contractual (Alfaro, 2004, pág. 18)

En conclusión una clausula de competencia debe ser necesaria para la finalidad del contrato que la contiene de forma tal que sin ellas la transacción no podría realizarse o podría realizarse pero en condiciones más inciertas, con un costo mayor o menores posibilidades de éxito. 


\subsection{La Clausula Inhibitoria de la Competencia debe ser Proporcionada:}

La proporcionalidad refiere a que la restricción que implica la clausula de no competencia, no debe ir más allá de lo necesario para garantizar su finalidad. La inhibición de competir no puede ser mayor que lo absolutamente indispensable para proteger el legítimo interés del acreedor de la misma. (Miranda Serrano, 2000, pág. 13) Señala como la necesidad de la restricción para la realización de la operación principal justifica la presencia de la clausula restrictiva pero, al mismo tiempo limita su alcance al requerir que sea lo menos restrictiva de la competencia posible sin merma de la finalidad económico - jurídica que le es propia. la obligación de no hacer debe ser razonable. Por ello, a fin de no juzgarla abusiva, se entiende que debe tener un plazo limitado, un espacio y una actividad definidos, ya que de lo contrario afectaría genéricamente la libertad del deudor (Lorenzetti, 2005, pág. 323). Autores franceses como (Burst, 1970, pág. 214) y (Plaisant, 1955, pág. 65 ) consideran que en los contratos de licencia las restricciones deben ser limitadas en el tiempo y en el espacio

La proporcionalidad de las clausulas de no competencias es evaluada por los tribunales desde varios aspectos, su duración, el ámbito geográfico, el alcance y su contenido

\subsubsection{Duración}

En cuanto el termino de duración la jurisprudencia y legislación Europeas han establecido un término máximo de 5 años de duración para este tipo de clausulas, en procesos de compraventa, integración o cesión de empresas, el Tribunal de 
Justicia Europeo mediante (Sentencia , 1985) ${ }^{20}$, asunto Remia B.V. y otros contra Comisión de las Comunidades Europeas, caso en el cual Remia cede una parte de la empresa Luycks " obligándose por un período de 10 años no realizar directa o indirectamente producción o venta de salsas en el mercado holandés Además, se obligó por un período de cinco años no realizar directa o indirectamente producción o venta de encurtidos o condimentos en países europeos, consideró que tales clausulas eran anticompetitivas porque su duración excedía lo necesario para garantizar la real adquisición de la empresas transferidas.

El tribunal de justicia señala los siguientes criterios para establecer la proporcionalidad en el plazo de una clausula de no competencia en esta clase de operaciones a saber:

1) el tiempo requerido por el comprador para conservar la clientela;

2) la frecuencia con que los consumidores del mercado relevante cambian de marca y tipos

3) el tiempo que se requiere para que los consumidores acepten nuevos productos y marcas

4) el tiempo que necesitaría el vendedor en caso que quisiera volver al mercado y recuperar sus clientes

5) la duración de acuerdos conexos con la cláusula, como el que permite al comprador de la empresa usar la marca del vendedor o su red de ventas.

\footnotetext{
${ }^{20}$ Sentencia , 42/84 Remia B.V. y otros contra Comisión de las Comunidades Europeas (Tribunal de Justicia Europeo (Sala Quinta) 11 de julio de 1985)
} 
El (Reglamento nº 2790/1999 CE, 1999) en su Artículo limita las duración de las clausulas de no competencia a cinco años en acuerdos verticales y las clausulas de no competencia con efectos post contractuales a un año tras la expiración del acuerdo. Pero si llegaren a tratarse de conocimientos técnicos (knowhow) que no fueren de conocimiento público la duración de la prohibición de competencia para el uso de los mismos podría ser ilimitada.

De otra parte la (Comunicación de la Comisión sobre las restricciones directamente vinculadas a la realización de una concentración y necesarias a tal fin C56/03, 2005) para el caso de cesión de empresas las clausulas inhibitorias de la competencia están justificadas durante un máximo de tres años cuando la cesión de la empresa incluye la transferencia de la clientela fidelizada como fondo de comercio y los conocimientos técnicos, sin embargo la Comisión Europea en algunos casos excepcionalmente consideró justificados plazos más largos (Decision , 2000) ${ }^{21}$. Cuando solo se transfiere el fondo de comercio dichas clausulas están justificadas por periodos de dos años (Decision , 1999).

En los contratos de agencia comercial la clausula de no competencia post contractual sólo será válida para un período máximo de dos años después de la terminación del contrato (Directiva 86/653/CEE relativa a la coordinación de los derechos de los Estados Miembros en lo referente a los agentes comerciales independientes, 1986).

${ }^{21}$ Decision , Comp/M 1980 Volvo - Renault (Comision Europea 1 de septiembre de 2000) 
En conclusión la duración de la clausula de no competencia en un contrato será la necesaria para garantizar la real transferencia del derecho o la protección del KnowHow. Lo cual podría variar dependiendo de la naturaleza del negocio jurídico. Para ello es preciso también diferenciar los efectos contractuales y post contractuales de la clausula. En un contrato de ejecución sucesiva como el de arrendamiento de establecimiento de comercio, trasferencia de KnowHow, o franquicia, la duración de los efectos contractuales de la clausula de no competencia se justifica precisamente en la duración del contrato principal, entendiendo que dicha restricción es necesaria durante toda su vigencia.

En cuanto a la duración de la clausula de no competencia con efectos post contractuales, varia entonces conforme a la necesidad de proteger la consolidación o protección del derecho que se transfiere o readquiere, la doctrina Europea como hemos visto en las anteriores normas, ha establecido periodos de un año a tres años dependiendo del interés que se desea proteger así aceptando inclusive duración indefinida para proteger conocimientos técnicos de carácter reservado (Reglamento nº 2790/1999 CE, 1999) sin embargo existe una limitación de un año para uso del Knowhow de carácter no reservado para acuerdos verticales como la franquicia; en la venta de fondos de comercio de dos años o hasta tres si incluye la la transferencia de la clientela fidelizada al fondo de comercio y los conocimientos técnicos; y dos años en la agencia comercial. Pero a nuestro juicio tales plazos si bien tratan de estandarizar una limitación en términos razonables dado el comportamiento del mercado, no limitan la posibilidad términos de duración más largos o cortos, en casos específicos cuando quiera que estos se 
justifiquen en la protección de derechos cuya consolidación pueda superar tales plazos.

\subsection{2 Ámbito Geográfico}

Una clausula de no competencia pierde su eficacia si no limita sus efectos en un territorio determinado, este tipo de cláusulas señalan que la restricción no puede exceder el ámbito geográfico en que produce efectos la convención principal, así si un determinado establecimiento de comercio solo tiene el mercado en una zona muy limitada de una ciudad, en caso de venta, la clausula de no competencia solamente podrá limitar su restricción a esta zona de influencia y no a toda la ciudad.

La (Comunicación de la Comisión sobre las restricciones directamente vinculadas a la realización de una concentración y necesarias a tal fin C56/03, 2005) señala que el ámbito geográfico de aplicación de una clausula inhibitoria debe restringirse a la zona donde el vendedor ofrecía los productos o servicios de referencia antes del traspaso, pues se considera que no es necesario proteger al comprador de la competencia del vendedor en territorios en donde este no estaba presente y no ejercía ninguna influencia en el mercado, sin embargo se acepta que las clausulas de no competencia contemplen ampliación de territorios en los que el vendedor planeaba introducirse siempre y cuando hayan efectuado inversiones . 
La (Directiva 86/653/CEE relativa a la coordinación de los derechos de los Estados Miembros en lo referente a los agentes comerciales independientes, 1986) señala en su artículo 20 que Una cláusula de no competencia sólo será válida en el supuesto y en la medida en que estuviere dirigida al sector geográfico o al grupo de personas confiados al agente comercial.

En conclusión el ámbito geográfico de influencia de una clausula de no competencia no puede ir más allá del espectro de influencia que tenia la prestación principal, como la zona de influencia de un establecimiento vendido o franquiciado o el territorio en que el agente comercial desempeñaba la promoción de los negocios del agenciado.

\subsubsection{Alcance:}

El alcance refiere a la cantidad de sujetos que quedarían afectos a la obligación de no competencia, estableciéndose que la misma únicamente podría vincular a los contratantes, La doctrina argentina al respecto considera que las clausulas de no competencia no pueden imponer restricciones a terceros sino sólo a la propia libertad de acción de los participantes de la transacción (Dictamen , 2008) CNDC

Pero en desarrollo de diferentes clases de negocios y el tamaño de las empresas esta limitación no puede suponerse absoluta, pues es legítimamente permitido y proporcional que en aras de la efectividad de la protección del derecho a transferir, la inhibición de competencia pueda darse sobre otras personas no intervinientes, como el caso de agentes comerciales o a las filiales y subsidiarias de una 
sociedad Matriz, condiciones especiales que por su grado de subordinación hacia el obligado y su actividad en la cadena empresarial pudieren ser utilizadas para evadir la prohibición o son determinantes para su efectividad. Así lo ha considerado la legislación Europea que en (Comunicación de la Comisión sobre las restricciones directamente vinculadas a la realización de una concentración y necesarias a tal fin C56/03, 2005) señala que el vendedor puede comprometerse en nombre propio, en el de sus empresas filiales y de sus agentes comerciales, pero la imposición de esa obligación a otras personas es inadmisible.

En conclusión una clausula de no competencia, solo puede inhibir la actividad comercial de los contratantes, pudiendo extenderse única y exclusivamente a agentes comerciales, filiales y subsidiarias, en la medida que están subordinados comercialmente a alguno de los contratantes y su inhibición sea esencial para la adecuada protección de los derechos que por el pacto se protejan.

\subsubsection{Contenido:}

Una clausula inhibitoria de no competencia no puede coartar de manera absoluta la actividad empresarial del deudor o su actividad dentro del mercando, en tal virtud solamente puede enervar la competencia exclusivamente en aquellos productos o servicios que constituyan la actividad económica de la empresa traspasada o de la obligación principal. (Comunicación de la Comisión sobre las restricciones directamente vinculadas a la realización de una concentración y necesarias a tal fin $C 56 / 03,2005)$ La norma comunitaria no considera necesario proteger al comprador de la competencia del vendedor en aquellos mercados de 
productos o servicios en los que la empresa traspasada no operase antes de la tradición.

En la (Decisión , 2001)²2la Comisión Europea al analizar la adquisición de EIRCELL por parte de Vodafone Group PLC que contiene una clausula de no competencia para que EIRCEL por 3 años en Irlanda, autorizo la operación al considerar que la clausula de no competencia es accesoria a la concentración en la medida en que se relaciona con los servicios de telecomunicaciones móviles y es necesario para transferir el bien y el KnowHow.

En conclusión para que una clausula que inhiba la competencia sea proporcional deberá limitar su alcance única y exclusivamente a los mercados, productos y/o servicios que sean necesarios para proteger el derecho transferido.

\section{Régimen de Responsabilidad}

Hemos querido destinar un breve espacio al análisis de la responsabilidad derivada del incumplimiento de la clausula de no competencia como quiera que existen situaciones que han oscurecido un poco el tema.

En primer lugar como lo hemos sostenido en esta investigación, las clausulas de no competencia dependiendo de la naturaleza del contrato pueden tener efectos durante la ejecución del contrato principal o con posterioridad a su ejecución, así

\footnotetext{
22Decisión , (COMP/M.2305 — Vodafone Group PLC/EIRCELL (Comision Europea 2 de marzo de 2001).
} 
si pensamos en una clausula de no competencia incluida en un contrato de compraventa de un fondo de comercio, necesariamente hablaríamos de efectos post contractuales de la clausula, pero la situación varía si nos encontramos ante un contrato de franquicia, cuya inhibición de competencia puede tener tanto efectos durante la ejecución del contrato, como con posterioridad al mismo. Se ha puesto en discusión entonces, la existencia de responsabilidad contractual cuando se está ante lo efectos post contractuales de la clausula, bajo el argumento que una vez extinguido el contrato no podría predicarse responsabilidad derivada del mismo. (Josserand, 1939) Señalaba que mientras que no exista contrato y desde el instante en que ya no haya contrato, los problemas de responsabilidad que puedan surgir, incluso con ocasión de un contrato futuro o pasado, siguen siendo problemas de responsabilidad delictual.

Otra situación que ha oscurecido el tema, para determinar la clase de responsabilidad derivada del incumplimiento de la obligación de no hacer competencia, es la fuente de la obligación, pues en este sentido hay autores consideran como un acto de competencia desleal este tipo de conducta (Morles Hernandez, 2004, pág. 86) lo cual conduciría entonces una fuente de responsabilidad extracontractual derivada de la conducta delictuosa del agente y no un incumplimiento de la obligación contractual por parte del deudor.

Se ha dicho que estamos en presencia de responsabilidad contractual, cuando la obligación de indemnizar surge como consecuencia del incumplimiento de un contrato, es decir existiendo un vinculo contractual anterior al hecho que es imputable al deudor, en cambio cuando no existe tal vinculo sino que la obligación 
de indemnizar la impone la ley, como consecuencia de un hecho ilícito, imputable a un sujeto estamos en presencia de la responsabilidad extracontractual o delictual (Alessandri Rodriguez \& Somarriva Undurraga, 1941, pág. 192), entonces si queremos enmarcar este deber de reparación en el ámbito de la responsabilidad contractual será menester tal y como lo sostiene (Duci Claro, 1971, pág. 17) la presencia de un acreedor y un deudor, una obligación contractual y el incumplimiento por parte del deudor de dicha obligación y aunque las partes estén vinculadas por un contrato, si el daño no se origina en el incumplimiento de una de las obligaciones surgidas de ese contrato, no se está en el campo de la responsabilidad contractual sino extracontractual (Arrubla P., 2008, pág. 377). Así, si el vínculo obligatorio reconoce su génesis o antecedente en un contrato, su cumplimiento debe también estar regido por el principio de buena fe contractual (Ruggiero, 1929, pág. 74)

Teniendo claro estos conceptos pasemos a decir que es necesario distinguir entre el efecto concomitante o ulterior que pueda tener una clausula respecto de la existencia del contrato que le da origen, pudiendo extender sus efectos, sea en la etapa contractual o más allá de este, en la etapa post contractual. (Alterini, 1998, pág. 529) Acertadamente señala que lo post contractual sólo denota lo que es ulterior al cumplimiento de las obligaciones principales del contrato, entonces cuando se vulneran las obligaciones que subsisten después de que el contrato ha agotado sus efectos jurídicos se encuadra dentro del campo contractual de responsabilidad. Una obligación contractual puede tener eficacia una vez fenecido el contrato lo cual no impide que la responsabilidad generada por su 
incumplimiento sea de índole contractual, pues la expiración de un contrato hace desaparecer, solo en apariencia el vínculo contractual entre las partes contratantes ya que en realidad estas se mantienen ligadas por los criterios de la buena fe, así como por los deberes de lealtad de efecto ulterior (Rezzónico, 1998, pág. 530)

Queremos señalar que sin importar que la clausula de no competencia tenga efecto en la etapa contractual o post contractual el régimen de su responsabilidad será contractual, como lo sostiene (Ancel, 1999, pág. 776) la fuerza del contrato sobrevive a su fin, cualesquiera haya sido la vía de extinción, y por ende dará origen a responsabilidad contractual en los casos en que subsistan obligaciones inherentes al contrato.

Concluimos que el daño presentado a consecuencia de la violación de una clausula inhibitoria de efectos post contractuales, da lugar a una responsabilidad que es contractual, Esto se debe a la ultra actividad del contrato ya que la satisfacción de ese deber deviene necesario, para que uno de los ex contratantes no frustre la ventaja otorgada y obtenida contractualmente (Leiva Fernandez, 2002). El daño se origina precisamente en una clausula, accesoria, subsidiaria y necesaria, para la ejecución de esta clase de contratos, lo que se reclama es precisamente la violación de la obligación contractual y no los actos de competencia propiamente dichos por ende su fuente y responsabilidad obedece al 
contrato del cual emana aunque sus efectos sean posteriores al cumplimiento de la prestación principal.

Finalmente, debemos aclarar que cuando se denuncian actos de concurrencia en violación de un pacto de no competencia válidamente celebrado, se está en presencia de una infracción a una obligación contractual, y por lo tanto resulta inexacto hablar de competencia ilícita o desleal, pues se trata de actos que implican el incumplimiento de un deber del deudor violando la ley del contrato, que no necesariamente pueden encajar dentro que lo que podemos entender como desleales; es preciso anotar que los actos de competencia realizados por el deudor implican la violación de una competencia prohibida (Legal o Contractualmente) mas no desleal, estaríamos ante una competencia ilícita y en consecuencia en un régimen de responsabilidad extracontractual, solo si tales actos derivaran de la conducta de un tercero quien no solo compite en el mercado sino que lo hace a través de maniobras fraudulentas. Al ser la fuente del daño derivado del incumplimiento de la obligación de la inhibición de concurrencia una competencia prohibida de orden contractual y no un acto de competencia desleal, se ratifica sin lugar a dudas, que el régimen de responsabilidad que se le aplica a este caso es el contractual y no el extracontractual que amparara a los actos de competencia desleal cometidos por un tercero. 


\section{Conclusiones}

Para el derecho Colombiano, es Constitucionalmente posible que un individuo voluntariamente decida abstenerse de realizar una actividad y dejar de competir, siendo reprochable esta conducta en la medida que sea presionada, impuesta o se realice con el ánimo de falsear esta competencia.

Las clausulas de no competencia, constituyen instrumentos valiosos y necesarios para evitar competencia desleal o garantizar la real adquisición y dominio de bienes inmateriales como el KnowHow o la clientela, la adquisición, transferencia y comercialización de nuevas tecnologías, o para permitir la realización de negocios y formas contractuales que permitan al mercado y a sus empresas ser más eficientes. 
Las clausulas de no competencia son aceptadas si reúnen una serie de requisitos en primer lugar cuando son accesorias en relación al objeto principal del contrato no restrictivo, ser además absolutamente necesarias para garantizar al acreedor el disfrute de los frutos legítimos del contrato o para protegerlos contra un uso injusto de esos frutos por la otra parte y ser razonable comparada con el beneficio que obtiene el público en general

El ordenamiento jurídico Colombiano permite que en ejercicio de su autonomía contractual, las partes pueden estipular clausulas de no competencia, siempre y cuando sean accesorias necesarias, proporcionadas y razonables.

Las restricciones principales, desnudas o carácter general al comercio, son ilegales per se. En consecuencia una clausula inhibitoria de la competencia para que no sea considerada prima facie ilegal por objeto ilícito, debe ser accesoria y estar directamente relacionada con la realización de una operación principal no restrictiva.

Una clausula de competencia debe ser necesaria para la finalidad del contrato que la contiene de forma tal que sin ellas la transacción no podría realizarse o podría realizarse pero en condiciones más inciertas, con un costo mayor o menores posibilidades de éxito.

La clausula de no competencia debe ser proporcionada, no debe ir mas allá de lo necesario para garantizar su finalidad, no puede ser mayor que lo absolutamente indispensable para proteger el legítimo interés del acreedor de la misma dicha 
proporcionalidad es evaluada por los tribunales desde varios aspectos, su duración, el ámbito geográfico, el alcance y su contenido

La duración de una clausula de no competencia en el derecho europeo varía según el interés a proteger o si se trata de efectos contractuales o post contractuales, no pueden pactarse clausulas indefinidas se reconoce validez a clausulas de este tipo hasta por cinco años, en el caso de la transferencia de una empresa tres años si incluye clientela fidelizada y conocimientos técnicos y de dos años cuando sólo se transfiere la clientela. Sin embargo no se limitan la posibilidad términos de duración más largos, en casos específicos cuando quiera que estos se justifiquen en la protección de derechos cuya consolidación pueda superar tales plazos.

Una clausula de no competencia pierde su eficacia si no limita sus efectos en un territorio determinado, que no puede exceder el ámbito geográfico en que produce efectos la convención principal, como la zona de influencia de un establecimiento vendido o franquiciado o el territorio en que el agente comercial desempeñaba la promoción de los negocios del agenciado.

una clausula de no competencia, solo puede inhibir la actividad comercial de los contratantes, pudiendo extenderse única y exclusivamente a agentes comerciales, filiales y subsidiarias, en la medida que están subordinados comercialmente a alguno de los contratantes y su inhibición sea esencial para la adecuada protección de los derechos que por el pacto se protejan. 
Para que una clausula que inhiba la competencia sea proporcional deberá limitar su alcance única y exclusivamente a los mercados, productos y/o servicios que sean necesarios para proteger el derecho transferido.

El daño presentado a consecuencia de la violación de una clausula inhibitoria de efectos post contractuales, pues este se origina precisamente en una clausula, accesoria, subsidiaria y necesaria, para la ejecución de esta clase de contratos, lo que se reclama es precisamente la violación de la obligación contractual y no los actos de competencia propiamente dichos por ende su fuente y responsabilidad obedece al contrato del cual emana aunque sus efectos sean posteriores al cumplimiento de la prestación principal. 


\section{BIBLIOGRAFÍA}

Adame Goddard, J. (2001). ¿Deben Ser Válidas Las Cláusulas De No Competencia En El Derecho Mexicano? Boletin Mexicano de Derecho Comparado, 687-730.

Aguilar Álvarez de Alba, J. B. (2000). La Libre Competencia. México D.F: Oxford.

Águila-Real, J. A. (2004). La prohibición de los acuerdos restrictivos de la competencia Una concepción privatística del derecho antimonopolio. InDret revista para el análisis del Derecho , 1 -31.

Alessandri Rodriguez, A., \& Somarriva Undurraga, M. (1941). Derecho Civil de las Obligaciones Tomo III. Santiago: Nascimento.

Alfaro, j. (2004). la prohibicion de los acuerdos restrictivos de la competencia. indret , 253.

Alterini, A. (1998). Contratos civiles, comerciales, de consumo: teoría general. Buenos aires: Abeledoperrot.

Ancel, P. (1999). Forceobligatoire et contenuobligationel du contrat. revuetrimestrielle de droit civil $n^{\circ} 4,771-810$.

Archila, M. v. (2001). Universidad Javeriana . Recuperado el 15 de noviembre de 2010, de Los Precios Predatorios una Forma de Abuso de la Posicion Dominante: http://www.javeriana.edu.co/biblos/tesis/derecho/dere2/Tesis13.pdf 
Arrubla P., J. (2008). Contratos Mercantiles Teoria general del Negocio Mercantil Tomo I. Bogota: Dike.

Arrubla Paucar, J. (2003). Contratos Mercantiles Tomo II. Bogota: Dike.

Arthur, C. (2000). A Workable Rule of Reason: a Less Ambitious Antitrust Role for the Federal Courts. Antitrust Law Journal no 68 .

Bellamy, C., \& Child, G. (1992). Derecho de la Competencia en el Mercado Comun. Madrid: Civitas.

Burst, J. (1970). Breveté et licencié. Paris.

Cavanellas de las Cuevas, G. (1994). Contratos de licencia y Transferencia de Tecnología. Buenos Aires : Heliasta.

Creed, J. F., \& Bangs, R. B. (1960). Know-How Licensing and Capital Gains. Patent Trademark \& Copyrights Journal. Res. \& Ed. 93.

De Sola Cañizares, F. (1962). Tratado de Derecho Comercial Comparado Tomo II. Barcelona : Montaner y Simon S A.

Duci Claro, C. (1971). Responsabilidad Civil. Santiago: Editorial Juridica de Chile.

Echeverri Uribe, A., Díaz Rivera, J., \& Mick Forero, J. (2006). Universidad Javeriana . Recuperado el 11 de noviembre de 2010, de PRACTICAS RESTRICTIVAS DE LA COMPETENCIA EN LATINOAMERICA Y EL CARIBE: http://www.javeriana.edu.co/biblos/tesis/derecho/dere8/DEFINITIVA/TESIS04.p df

Farnsworth, E. A. (1990). Contracts 2nd Ed. New York: Little Brown and Company .

Flint Blanck, P. (2002). TRATADO DE DEFENSA DE LA LIBRE COMPETENCIA. Lima: Fondo Editorial de la Pontificia Universidad Catolica del Perú.

Garrigues, J. (1974). Curso de derecho Mercantil Tomo I. Madrid: Imprenta Aguirre.

Goldschmidt, R., Rodríguez, G., \& Ruiz, I. B. (2008). Curso de Derecho Mercantil . Caracas : Texto C.A. . 
Guyenot, J. (1975). Curso de derecho comercial . Buenos Aires: Ediciones Jurídicas Europa-América.

Ibarra, G., \& Miranda, A. (2000). La Practica de fijacion Unilateral de precios y su Aplicación en Colombia. CEDEC Centro de Estudios de Derecho de la Competencia , 55.

Josserand, L. (1939). De l'esprit des droit et de leurrelativité ;théorie dite de l'abus des droits (décima ed.). Paris: Dalloz.

Kjolbye, L. (2004). The new commision guidelines on the application the article 81 (3) : An Economic Approach to article 81. European Competition Law Review No 25.

La Pera, S. (1974). Cuestiones de Derecho Comercial Moderno . Buenos Aires: Astrea .

Leiva Fernandez, L. (2002). La Responsabilidad Postcontractual. La Ley, 1336-1340.

Lorenzetti, R. L. (2005). Código Civil Comentado. Doctrina Jurisprudencia Bibliografía. Contratos. Parte Especial. Tomo I. Santa Fe : Rubinzal Culzoni Editores.

Martí Miravalls, J. (2007). El contrato de franquicia y su relacion con el derecho anti trust comunitario: acuerdos verticales. Revista de derecho patrimonial No 18.

Martí Miravalls, J. (2008). Las restricciones accesorias, necesarias y proporcionadas en el contrato de franquicia. Actas de Derecho Industrial y de Derechos de autor , 341-370.

Martinez Medrano, G. (enero de 2006). La proterccion de las marcas de hecho Recuperado el 10 de 05 de 2012, de http://works.bepress.com/cgi/viewcontent.cgi?article=1067\&context=martinezm edrano\&sei-

redir=1\&referer=http\%3A\%2F\%2Fscholar.google.es\%2Fscholar\%3Fq\%3Dfond 0\%2Bde\%2Bcomercio\%2Bgood\%2Bwill\%26hl\%3Des\%26lr\%3Dlang_es\%26as _sdt\%3D0\#search=\%22fondo\%20de\%20comercio\%

Meese, A. J. (2003). Price theory, competition, and the rule of reason. University of Illinois Law Review, 77-105. 
Miranda Londoño, A. (7 de septiembre de 1992). Centro de Estudios de la Competencia CEDEC. Recuperado el 9 de noviembre de 2010, de Anotaciones sobre el Derecho Antimonopolistico en Estados Unidos de America: http://centrocedec.files.wordpress.com/2010/06/anotaciones-sobre-derechoantimonopolistico-de-e-e-u-u-alfonso-miranda-Iondono.pdf

Miranda Londoño, A. (1999). El regimen General de la libre Competencia. Estudios De Contratación Internacional , 17-47.

Miranda Serrano, L. M. (1994). Las Concentraciones Economicas, Derecho Europeo y Español. Madrid: La Ley.

Miranda Serrano, L. M. (2000). Restricciones Accesorias y Practicas Colusorias. Derecho de los Negocios No 122 , 1-50.

Morles Hernandez, A. (2004). Compenido de derecho merchantil I. Caracas: U Catolica andres Bello.

OECD, O. f.-O., \& BID. (2009). Organisation for Economic Co - Operation and Development. Recuperado el 16 de 11 de 2010, de DERECHO Y POLÍTICA DE LA COMPETENCIA EN COLOMBIA: http://www.oecd.org/dataoecd/33/12/44111213.pdf

Ortiz Blanco, L. (2005). Derecho de la competencia europeo y español: Curso de iniciación, Volume 6. Madrid : Dykinson.

Pascual Y Vicente, J. (2002). Diccionario de Derecho y Economía de la Competencia en España y Europa. Madrid: Civitas.

Plaisant, R. (1955). nota al fallo de casacion de Paris del 2 de julio de 1952. Annales de la propiete industrielle, artistique et litterarie .

Ravassa Moreno, G. J. (2001). Derecho Comercial Tomo I. Bogota : Ediciones Juridicas Gustavo Ibañez .

Rezzónico, J. C. (1998). Principios fundamentales de los contratos. Buenos Aires: Astrea.

Ruggiero, R. (1929). Instituciones de Derecho Civil Vol. I. Madrid : Reus.

Turner, A. (1962). The Law of trade Secrets . Londres.

UNCTAD, U. N. (2004). Manual Para La Formulación y Aplicación de las Leyes de Competencia. Ginebra: UNCTAD. 
Uribe, C. A. (2006). ¿ Los Acuerdos Horizontales en colombia se resuelven por la regla per se ? Vniversitas No 112, 149-191.

Van Notten, M. (1963). Know how licensing in the common market. New York University lew review $T 38$.

Velilla, M. A. (2002). Introduccion al derecho de los Negocios. Bogota : Ediciones Juridicas Gustavo Ibañez.

Zurimendi Isla, A. (2003). Las restricciones verticales a la libre competencia. Thompson Civitas .

\section{REFERENCIAS JURISPRUDENCIALES Y DECISIONES DE ORGANOS DE COMPETENCIA}

Addyston Pipe and Steel Co. v. United States, , 85 F. 271 ( the United States Court of Appeals for the Sixth Circuit 1898).

Arizona vs Maricopa County Medical Society , 457 u.s. 332 (Supreme Court 1982).

Concepto , 58216 (Superintendencia de Industria y Comercio de Colombia 12 de septiembre de 2000).

Decision , 90/410 (Comision Europea 13 de julio de 1990).

Decision , IV/M 1482 KingFisher/Grosslabor (Comision Europea 12 de abril de 1999).

Decision , Comp/M 1980 Volvo - Renault (Comision Europea 1 de septiembre de 2000).

Decisión , (COMP/M.2305 - Vodafone Group PLC/EIRCELL (Comision Europea 2 de marzo de 2001).

DECISIÓN 285 C A. (21 de marzo de 1991). Lima.

Dictamen, No 704 (Comisión Nacional de Defensa de la Competencia Argentina 23 de Diciembre de 2008).

Resolucion , 46325 (Superintendencia de Industria y Comercio 31 de agosto de 2010). 
Sentencia , 42/84 Remia B.V. y otros contra Comisión de las Comunidades Europeas (Tribunal de Justicia Europeo (Sala Quinta) 11 de julio de 1985).

Sentencia , Radicación número: 54001-23-31-000-2000-1749-0 (Consejo de Estado de Colombia 24 de agosto de 2001).

Sentencia, Dalloz, 2002.2491 (Cour de Cassation français 10 de julio de 2002).

Sentencia , 2001-264 (Tribunal Administrativo de Cundinamarca 27 de noviembre de 2003).

Sentencia (Corte Suprema de Justicia de Colombia Sala Plena 18 de junio de 1973).

Sentencia Constitucionalidad, C-996 (Corte Constitucional 29 de noviembre de 2006).

Sentencia Constitucionalidad, C524 (Corte Constitucional 1996).

Sentencia Constitucionalidad, C-093 (Corte Constitucional de Colombia 1996).

Sentencia de Constitucionalidad, C-535 (Corte Constitucional de Colombia 1997).

Sentencia de Constitucionalidad , c- 624 (Corte Constitucional de Colombia 1998).

Sentencia de Tutela , T-240 (Corte Constitucional de Colombia 1993).

Standard Oil Co of New Jersey vs United States, 221 u.s. 1 (Supreme Court USA 1910).

\section{REFERENCIAS NORMATIVAS}

Codice Civile . (1942). art 2125 y 2526 . Roma, Italia .

Codigo Civil Colombiano. (1873). Bogota, Colombia.

Codigo de Comercio Colombiano decreto ley 410. (1971). Bogota, Colombia .

Comunicación de la Comisión . (2008). directrices relativas a la aplicación del apartado 3 del Artículo 81 del Tratado 2004/c 101/08. Comunidad Europea .

Comunicación de la Comisión sobre las restricciones directamente vinculadas a la realización de una concentración y necesarias a tal fin C56/03. (05 de marzo de 2005). Union Europea 
Constitucion Política de Colombia . (1991). art 333 . Bogota, Colombia .

DECRETO 2153. (30 de diciembre de 1992). Bogota, Colombia.

Directiva 86/653/CEE relativa a la coordinación de los derechos de los Estados Miembros en lo referente a los agentes comerciales independientes. (18 de diembre de 1986). Bruselas.

LEY 155 Por la cual se dictan algunas disposiciones sobre prácticas comerciales restrictivas. (14 de Diciembre de 1959). Bogota, Colombia.

Ley 1340 . (24 de julio de 2009 ). Colombia .

ley 222 . (20 de diciembre de 1995). Bogota, Colombia .

Reglamento no 2790/1999 CE. (22 de diciembre de 1999). Bruselas, Bélgica.

Sherman Antitrust Act. (2 de julio de 1890). United States Of America .

Tratado Constitutivo de la Comunidad Europea. (7 de febrero de 1992). Maastricht . ART 81 


\title{
PACTOS DE NO COMPETENCIA, EN LA ENAJENACIÓN DE ESTABLECIMIENTOS DE COMERCIO ${ }^{23}$
}

\author{
Rafael Leonardo Páez Fuentes ${ }^{24}$
}

SUMARIO: RESUMEN - INTRODUCCION - 1. Definición y naturaleza de los Fondos de Comercio 2.Accesoriedad Necesidad y Subsidiaridad 2.1Necesidad cuando hay venta parcial del Establecimiento de Comercio 3. Proporcionalidad 3.1. Duración 3.2. Ámbito Geográfico. 3.3. Alcance 3.4. Contenido 3.5 Tratamiento de la falta de Proporcionalidad - CONCLUSIONES - BIBLIOGRAFIA

\section{RESUMEN}

En reciente resolución la Superintendencia de Industria y Comercio ha establecido la posibilidad de pactar clausulas de no competencia en procesos de integración empresarial dando paso a la aplicación de la regla de la razón, y la doctrina de las restricciones accesorias de la competencia, este trabajo analiza la posibilidad de pactar clausulas de no competencia dentro del contrato de compraventa de fondos de comercio, y los requisitos que éstas deben cumplir dentro del ordenamiento jurídico Colombiano para ser consideradas admisibles.

\footnotetext{
${ }^{23}$ El presente artículo surge como resultado de la investigación desarrollada al interior del grupo de investigación en la Maestría en Derecho Contractual Público y Privado de la Universidad Santo Tomas, Bogotá D.C

${ }^{24}$ Abogado. USTA, Especialista en Derecho Financiero. U Rosario
} 


\section{Palabras Clave:}

Clausulas De No Competencia, Restricciones Accesorias, Regla De La Razón, clausula de no restablecimiento.

\section{ABSTRACT}

In recent resolution of the Superintendency of Industry and Commerce of Colombia has established the possibility of negotiating non-compete clauses in business integration processes giving rise to the application of the rule of reason, and the doctrine of ancillary restraints of competition, this analyzes the possibility of negotiating non-competition clauses in the contract of sale of goodwill, and the requirements they must meet within the Colombian legal system to be considered admissible.

\section{KEY WORDS}

Non-Compete clauses, Ancillary Restrictions, Rule of Reason 


\section{INTRODUCCIÓN}

Los pactos o clausulas de no competencia, entendidas como un acuerdo accesorio y necesario a un contrato, mediante el cual una persona se obliga para con otra a no realizar cierta actividad empresarial o profesional, durante un cierto tiempo y en un territorio delimitado, han sido recientemente aceptadas por la Superintendencia de Industria y Comercio de Colombia quien ha modificado el criterio de asumirlas como ilegales per se y acoger el criterio Europeo para el análisis de estos pactos a través de la doctrina de las restricciones accesorias de la competencia (Resolucion , 2010) ${ }^{25}$

La importancia de este tipo de estipulaciones radica en la protección de bienes comerciales como en knowhow la clientela etc., sin las cuales es muy difícil asumir este tipo de riesgos o se hace en condiciones más onerosas, resultando necesarias para asegurar el cumplimiento real del propósito principal del contrato, la tradición del fondo de comercio como universalidad, que solo se logra mediante el cumplimiento por parte del vendedor de prestaciones positivas y negativas como el caso de la obligación de inhibición de la competencia.

\footnotetext{
${ }^{25}$ Resolución , 46325 (Superintendencia de Industria y Comercio 31 de agosto de 2010)
} 
Hoy por hoy aunque empiezan a ser aceptadas en la legislación Colombiana, no existe un lineamiento sobre los aspectos que pueden determinar su validez y aplicabilidad en ciertos contratos, es por ello, que intentaremos a través de este trabajo con base en el desarrollo doctrinal y jurisprudencial especialmente Europeo, establecer los presupuestos para la estipulación valida en el derecho Colombiano de este tipo de cláusulas en la venta de establecimientos de comercio, en los que han sido aceptados como necesarios para garantizar el cumplimiento de una obligación principal o la transmisión efectiva del bien.

Para lograr nuestro objetivo partiremos de los requisitos de validez generales establecidos para este tipo de restricciones accesorias y posteriormente estudiaremos su aplicación en el contrato de compraventa de fondos de comercio a la luz del derecho comparado y la legislación Colombiana, definiendo su necesidad, subsidiaridad, y proporcionalidad 


\section{PACTOS DE NO COMPETENCIA, EN LA ENAJENACIÓN DE ESTABLECIMIENTOS DE COMERCIO}

Las clausulas accesorias de no competencia entendidas, como un acuerdo mediante el cual una persona se obliga para con otra a no competir directa 0 indirectamente con esta última, en la actividad económica que desarrolla, durante la vigencia del contrato que los vincula o posterior a su vencimiento, durante un cierto tiempo y en un territorio aparejando una sanción de tipo pecuniario o indemnizatorio en caso de incumplimiento de tal estipulación. Son cláusulas o pactos incluidos en un contrato por el que una persona asume la obligación de no competir en un cierto mercado con otra. (Adame Goddard, 2001, pág. 688). o aquellas que establecen dos empresas con el objetivo de no disputar la clientela en un mercado determinado durante un cierto tiempo (Pascual Y Vicente, 2002, pág. 136). Estas estipulaciones que durante largo tiempo fueron consideradas ilegales per se por la Superintendencia de Industria y Comercio, recientemente han sido aceptadas como validas dentro del ordenamiento jurídico Colombiano, en procesos de integración empresarial como fusiones, adquisiciones o compraventa 
de fondos comerciales, acogiendo la teoría de las restricciones accesorias de la competencia, bajo los lineamientos de la Unión Europea, tales clausulas son analizadas desde la regla de la razón siempre y cuando reúnan los presupuestos para su validez como lo son la Accesoriedad, Necesidad, Subsidiaridad, y proporcionalidad. A continuación analizaremos cada uno de ellos en desarrollo de la celebración de un contrato para la enajenación de un fondo de comercio, y establecer unas posibles reglas de interpretación para su validez.

\section{Definición y naturaleza de los Fondos de Comercio}

Para abordar de manera adecuada este tema y dada su especial naturaleza, empezaremos por definir el fondo o establecimiento de comercio. En la legislación Colombiana (Codigo de Comercio Colombiano , 1971) artículo 515 se define como un conjunto de bienes organizados por el empresario para cumplir los fines de la empresa, concepto que fue traído del derecho italiano(Gaviria Gutierrez, 1985, pág. 43) cuyo artículo 2555 del (Codice civile , 1942 ) define la hacienda o fondo de comercio como el conjunto de los bienes organizados por el empresario para el ejercicio de la empresa.

Un fondo de comercio se conforma por una reunión de bienes pero que están ligados por una finalidad que es la operación de la empresa. (Fontanarrosa, 1997, pág. 202) Señalaba que si bien la hacienda es un conjunto de bienes 
heterogéneos, tales bienes no aparecen meramente yuxtapuestos caóticamente, sino, por el contrario, se manifiestan como vinculados entre sí por una interdependencia funcional establecida por el empresario mediante una organización adecuada y tendiente a posibilitar y facilitar el ejercicio de su actividad de empresa.

Es entonces el fondo o establecimiento de comercio un conjunto de fuerzas productivas, derechos y cosas, que tanto interior como exteriormente se presentan como un organismo, con perfecta unidad, para los fines a que tiende, que no son otros que la obtención de beneficios en el orden comercial e industrial (Raymundo L. Fernández, 1993, pág. 340). Constituye una universalidad formada por todos los elementos que lo integran constituyendo un verdadero organismo económico(Gutierrez Zaldivar, 2001, pág. 1), una Universalidad y como tal reviste las características de un bien incorporal mueble (Figueroa Yáñez, Repertorio de legislación y jurisprudencia Chilenas Tomo I, 1996). Existe la discusión si el establecimiento de comercio es una universalidad de hecho o de derecho ante lo cual la mayoría de la doctrina lo cataloga como una universalidad de hecho (Alessandri R, Somarriva U, \& Vodanovic H, 1998, pág. 86 y ss ) puesto que no es susceptible del pasivo.

\section{Necesidad, Accesoriedad y Subordinación}

La primera característica para que una clausula de no competir pueda considerarse razonablemente valida es su accesoriedad, lo cual queda de 
presente en este objeto de estudio, pues partiremos de la hipótesis de una cláusula de no competencia accesoria al contrato de venta de un fondo de comercio, la que supondremos como una actividad no restrictiva.

Entendida la naturaleza del fondo de comercio como un bien que está compuesto por otra serie de elementos, analizaremos la subordinación y necesidad de una clausula de no competencia en su enajenación.

Empecemos por señalar que como lo sostiene (Miranda Serrano L. M., 2000) entre la operación principal que para nuestro caso sería el contrato de venta del establecimiento y la restricción que inhibiría de la competencia al vendedor, debe existir un vínculo sustancial y no meramente incidental, de modo que aunque la restricción sea separable de la prestación principal, su fin no es otro que contribuir a posibilitar su realización, pues llevan a concluir que nadie en esas circunstancias hubiera celebrado una operación idéntica sin la restricción.

En la legislación Europea la (Comunicación de la Comisión sobre las restricciones directamente vinculadas a la realización de una concentración y necesarias a tal fin C56/03., 2005) considera que para obtener el valor íntegro de los activos transferidos, el comprador debe gozar de algún tipo de protección frente a la competencia del vendedor que le permita fidelizar la clientela, asimilar y explotar los conocimientos técnicos. Las cláusulas inhibitorias de la competencia garantizan la cesión al comprador del valor íntegro de los activos transferidos, que, por lo general, comprende tanto activos materiales como inmateriales, como el fondo de comercio y los conocimientos técnicos desarrollados por el vendedor. 
Estas cláusulas no sólo están directamente vinculadas a la concentración, sino que también son necesarias para su realización, porque hay buenos motivos para creer que sin ellas no sería posible la venta de la totalidad de la empresa o de parte de la misma. Así se consideran generalmente admisibles las restricciones necesarias para proteger al comprador de la eventual competencia que el vendedor podría seguir ejerciendo haciendo uso de los activos transferidos (Creus Carreras, Amador Peñate, \& Pérez Olmo, 2006, pág. 77)

El Tribunal de defensa de la competencia de España (Resolución, 2003) ${ }^{26}$ estima que resulta de interés público la existencia de un mercado fiable de empresas, dotado de instrumentos que den seguridad a las partes en la compra y venta de empresas. Las cláusulas de inhibición de la competencia, debidamente limitadas en el tiempo y en su ámbito de aplicación, contribuyen a dicha seguridad al proteger los intereses de los compradores de empresas en los casos de transferencia de fondo de comercio y de conocimientos técnicos. Este Tribunal en (informe, 1993) $)^{27}$ en la que decide sobre la autorización a "ICI PAINTS ESPAÑA, S.A para un pacto de no competencia accesorio en la adquisición del negocio de pinturas para el repintado de carrocerías de vehículos automóviles de BARNICES VALENTINE, S.A por el cual la parte vendedora se compromete en nombre propio y en el de sus compañías filiales o asociadas a no realizar durante cinco años actividades que puedan competir con la parte del negocio transmitido a $\mathrm{ICl}$

\footnotetext{
${ }^{26}$ Resolución, Expte. A 313/02, Pacto Foodservice-Mercat (Tribunal de Defensa de la Competencia España 8 de abril de 2003)

${ }^{27}$ informe, expediente 40/92 (Tribunal de defensa de la Competencia 2 de marzo de 1993)
} 
PAINTS ESPAÑA S.A. señaló que "lo que caracteriza al establecimiento mercantil es la existencia de una organización, resultado de la actividad competitiva del empresario, que tiene la consideración de bien inmaterial y que puede representar un valor económico muy superior a la suma de los valores de los diversos elementos que lo integran. Conectado con esa idea de organización aparece el llamado fondo de comercio integrado por la clientela y las expectativas de negocio generadas por el empresario, el cual se contabiliza incluso como un elemento del activo cuando se adquiere a terceros a título oneroso. Estos elementos, clientela y expectativas de negocio, evidentemente no son susceptibles de una transmisión directa cuando se vende el establecimiento mercantil. Sin embargo, en el Derecho privado se obliga al vendedor a hacer todo lo posible por traspasárselos al adquirente. Esta imposición se hace efectiva fundamentalmente por medios indirectos, esto es, mediante el cumplimiento de dos diferentes tipos de obligaciones: una positiva, o de hacer, que suele consistir en entregar al comprador la lista de clientes y proveedores o hacer saber a éstos por medio de circulares y anuncios el cambio habido en la titularidad del negocio; y otra negativa, o de no hacer, que se articula normalmente, a través del pacto de no concurrencia por un período limitado en el tiempo y determinado territorialmente y circunscrito a determinados productos o servicios para afianzar y no desviar la clientela."

En Latinoamérica podemos citar el proceso de adquisición parcial de los fondos de comercio de Catyc SA por parte de la sociedad Sealed Air Argentina S A, Empresas dedicadas a la elaboración de materiales para envase y embalaje de productos, se establece una clausula accesoria de no competencia, en la cual los vendedores y accionistas se comprometían conjunta y mancomunadamente a no intentar y obtener ofertas para pedidos de suministro ni llevar a cabo o participar en la manufactura o fabricación de los productos que se comercializaban a través de los fondos transferidos por un periodo de tres años dentro de la republica argentina. La Comision Nacional de defensa de la Competencia Argentina en 
(Dictamen de concentracion, 2000) ${ }^{28}$ señaló que para que este tipo de clausulas sean aceptadas en el marco del análisis sobre sus efectos en la competencia, deben estar estrechamente relacionadas con la operación, subordinadas en importancia a las mismas y deben ser necesarias para su efectivización, concluye al respecto que en este caso, Sealed Air adquiere el fondo de comercio incluyendo todos los activos que pertenecen al vendedor o a cualquiera de los tenedores de su capital accionario, la clientela, conocimiento de procesos, activos intangibles utilizados para dirigir el fondo de comercio; por lo que para recibir todo el beneficio de la operación bajo análisis resulta razonable que esta deba contar con protección respecto de la competencia que pueda ejercer la vendedora en el caso que intentase retener la fidelidad de los clientes y explotar el conocimiento de sus procesos, considerando la racionalidad económica de la clausula de no competencia.

La Doctrina de manera generalizada ha aceptado la necesidad de restringir la competencia por parte del enajénate al comprador de un fondo de comercio, sobre la base de impedir la "competencia desleal" que preferiremos llamar competencia prohibida, del vendedor o de garantizar la efectiva trasferencia del bien, teniendo en cuenta que al estar compuesto de varios derechos o elementos como el derecho a clientela, al goodwilll, knowhowetc se debe garantizar por quien transfiere un establecimiento a su comprador su funcionalidad económica, lo cual

\footnotetext{
${ }^{28}$ Dictamen de concentracion, No 33 exp 064-020368/99 (Comision Nacional de Defensa de la Competencia de Argentina 20 de marzo de 2000)
} 
no ocurriría de manera efectiva si el vendedor pudiera re-establecerse en el área de influencia que el fondo de comercio enajenado y actuar en forma directa sobre la clientela cedida. Para(Schmidt, 1997, pág. 148), la cesión o transferencia del establecimiento presupone la toma de posesión del ámbito de actividades por parte del adquirente, lo que incluye también la revelación de secretos industriales, de fuentes de suministro y lugares de venta, de organizaciones, de usos comerciales, etc. A ello se le agregan obligaciones accesorias, normalmente la prohibición de competir. En igual sentido (Jimenez Sanchez, 2009, pág. 94) Señala que en la enajenación de un establecimiento de comercio comporta la trasmisión efectiva de la empresa como organización económica productiva en la que se integran elementos y relaciones inmateriales de difícil o imposible dominación jurídica, por lo cual se justifica la imposición al vendedor o cedente de una conducta particularmente intensa activa y pasiva que se materializa contractualmente en el establecimiento de una doble obligación de hacer y de no hacer que se concreta en una prohibición de competencia a que queda sujeto el vendedor o cedente.

(Certad Maroto, 2007, pág. 144) considera que en el supuesto de la compra-venta de hacienda, a la prestación principal de dar del vendedor se agregan otras de contenido distinto, unas de hacer como el subarriendo o la cesión del contrato de arrendamiento del inmueble en donde se halla la hacienda, otras de no hacer(como la de abstenerse de competir, obligaciones estas que no encontramos en la disciplina general de la compra-venta mercantil. 
La necesidad y subsidiaridad de una clausula de no competencia en la venta de en establecimiento comercial se sustenta entonces en que, de no existir la posibilidad de restringir la actuación del vendedor, mermaría ostensiblemente el interés del comprador en la adquisición de un fondo de comercio ya que no tendría resguardo contra su re-instalación, el Jurista Argentino (Martinez Medrano, LIMITACIÓN CONTRACTUAL A LALIBERTAD DE COMPETIR (Transferencia deactivos comerciales y clausulas de no competencia), 2004) señala que dentro de las pautas de lealtad comercial, o de usos honestos en el comercio como los menciona el Convenio de París, está la de no desviar la clientela por maniobras contrarias a los usos honestos en materia industrial y comercial. Esta obligación general toma forma concreta ante la venta de un establecimiento. Si el vendedor cobra un precio por la transferencia de un establecimiento y pacta el retiro de un determinado mercado, su regreso al mismo en violación a lo pactado, además de constituir un incumplimiento contractual es un acto de competencia desleal.

Las cláusulas que restringen el restablecimiento, entonces, son necesarias para preservar la lealtad comercial en los contratos de transferencia de establecimiento o de activos. Como lo señalo el profesor (Aguilar Álvarez De Alba, 2000, pág. 99)Todos los pactos de no competencia lícitos tienden a proteger los intereses que por avviamento tienen los agentes económicos, sus haciendas y aquellos derechos que tengan sobre su propiedad industrial. 
En conclusión las clausulas que inhiban la competencia del vendedor de un establecimiento comercial, son consideradas necesarias para asegurar y salvaguardar la transferencia del mismo dada la complejidad de bienes y derechos que lo integran. Sin embargo parte de la Doctrina extranjera que compartimos, ha considerado que para el caso de la venta o enajenación de fondos de comercio la clausula de no competencia, más que un pacto accesorio y necesario, constituye una obligación de la naturaleza del mismo, consecuencia del deber de evicción, y una derivación del principio de buena fe. (Goldschmidt, Rodríguez, \& Ruiz, 2008, pág. 169) Señalan que algunos autores franceses, vinculan esta obligación a la teoría del saneamiento del contrato de venta del fondo de comercio bajo la base que el re establecimiento del vendedor, perturba de la posesión pacifica de la cosa vendida con un hecho propio privándole de la clientela considerada como elemento del fondo de comercio.

Si tenemos en cuenta que elementos que conforman el Establecimiento de Comercio como la clientela, el Knowhow y otros de la propiedad industrial solo pueden ser transferidos de manera efectiva en la medida que exista un comportamiento de abstención por parte del vendedor quien nunca se desprende del todo de los mismos, se vuelve entonces una obligación natural para este contrato la inhibición de la competencia. (Garrigues J. , 1987, pág. 233) Señaló que las prohibiciones de competir que constituyan consecuencia implícita en la propia naturaleza de negocios jurídicos lícitos son admisibles, siempre que tales 
prohibiciones no excedan de los límites justificados por el contenido del negocio jurídico que las fundamenta.

La necesidad de las clausulas de no competencia en este contrato se fundamenta, en que constituyen casi la única herramienta efectiva para garantizar la real transferencia del fondo de comercio. Es por ello tratadistas como el profesor (Jimenez Sánchez, 2003, pág. 68) considera que la no concurrencia configura un deber inherente a cargo del transmitente, comprendida dentro de la obligación de entrega efectiva de la hacienda, con todos sus componentes, como valor patrimonial de explotación u organización económica productiva en donde se integran elementos y relaciones inmateriales de difícil o imposible dominación jurídica.Expresa (Garrigues J. , Curso de Derecho Mercantil Tomo I, 1993, pág. 233) como elemento económico esencial a la transmisión de una empresa, sea a título de venta, sea a título de arrendamiento nace una obligación de no hacer. El vendedor sobre el cual pesa la obligación de garantía del bien que trasmite, debe, como es lógico, abstenerse de todo acto que pueda afectar su integridad y sus cualidades productivas de beneficios.

El profesor (Fernandez, 1961, pág. 81) ha considerado igualmente que la obligación de no competir forma parte de la garantía de evicción que el vendedor debe a todo comprador, en consecuencia en la transferencia de un fondo de comercio va implícita la cláusula de no volver a establecerse con un comercio similar en la vecindad o en su radio de funcionamiento. Lo cual permite la 
obligación del vendedor de asegurar al comprador el justo goce del establecimiento adquirido, evitando toda competencia de su parte, absteniéndose de todo acto que importe desviar la clientela del fondo.

En síntesis podríamos asegurar que en el contrato de compraventa de fondos de comercio, la inhibición de competencia es no solo necesaria, sino que además constituye una obligación de la naturaleza del contrato pues permite la tradición de elementos de este,| como el KnowHow, el goodwill o la clientela, y en consecuencia estuviere expresamente pactada 0 no el vendedor deberá abstenerse de iniciar actividades que impidan la real transferencia del fondo.

Tan es así que algunos países optaron por introducir en su legislación la inhibición de concurrencia en este contrato, por ejemplo El Art. 2557 del (Codigo Civil Italiano , 1942) establece el Divieto di concorrenza. Por el cual quien aliena un fondo de comercio debe abstenerse por un periodo de cinco años a partir de la transferencia de iniciar una nueva empresa que por el objeto, ubicación u otras circunstancias que sea idónea para desviar la clientela de la hacienda cedida.

Brasil estableció en el artículo 1147 del nuevo (Codigo Civil, 2002) que no habiendo autorización expresa, el vendedor de un establecimiento no puede hacer competencia al adquirente en los cinco años subsiguientes a la transferencia. En aplicación de este articulo el Tribunal de Justicia del Estado de Paraná en 
(Sentencia de Apelacion, 2009) $^{29}$ manifestó que la referida limitación evita que haya mala fe en la venta del establecimiento, impidiendo que el vendedor recibiera el dinero por la negociación y luego en seguida pasara a explotar el mismo negocio, compitiendo de forma desleal en busca de la misma clientela con el comprador. Es procedente destacar que según se señala en fallo del tribunal de justicia de Sao Paulo (apelação, 2011) en la jurisdicción brasilera antes de la entrada en vigencia de esta norma del nuevo código civil, ya se aceptaba que en la venta de establecimientos de comercio existe de manera implícita una obligación de no restablecimiento.

Como lo ha señalado (Cabanellas De Las Cuevas, (2005, pág. 573) existe nutrida jurisprudencia que admite la validez de las cláusulas de no competencia, en el tanto sean necesarias para preservar la clientela de un fondo de comercio transferido y no afecten la libertad de trabajo. Ello suele resultar en la delimitación de un radio alrededor de la localización del fondo de comercio transferido, en el cual la competencia puede ser restringida. El Derecho en general, acepta la necesidad y subsidiariedad de las clausulas de no competencia en casos de enajenación de establecimientos comerciales, algunos países lo han plasmado expresamente en sus legislaciones y otros no han visto esta necesidad pues lo consideran como una obligación de la naturaleza del contrato.

\footnotetext{
${ }^{29}$ Sentencia de Apelacion, 0575775-3 (Tribunal de Justiça do Estado do Paraná 22 de septiembre de 2009)
} 
La superintendencia de Industria y Comercio mediante(Resolucion , 2010) aceptó la posibilidad de pactar cláusulas de no competencia en procesos de integración empresarial o venta de establecimientos de comercio, considerando que a través de las mismas, el comprador tiene la posibilidad de aprovechar las ventajas que le proporciona la garantía que podrá obtener el valor íntegro de la empresa adquirida de acuerdo con lo razonablemente necesario para lograr dicho objetivo, aceptando la teoría de las restricciones accesorias.

Sin embargo, bien vale la pena preguntarse, si en ausencia de pacto expreso que refiera sobre la no competencia del vendedor del fondo de comercio, sería posible exigir tal inhibición como de la naturaleza del contrato y en desarrollo del principio de la Buena fe contractual.

(Díez-Picazo Y Ponce De León, 1963, pág. 137) Define a la buena fe como rectitud y honradez en el trato y supone un criterio o manera de proceder a la cual las partes deben atenerse en el desenvolvimiento de las relaciones jurídicas y en la celebración, interpretación y ejecución de los negocios jurídicos. (Larenz, 1958, pág. 142) entiende la buena fe como el deber que cada uno debe guardar a la palabra dada y no defraudar la confianza o abusar de ella, forma la base indispensable de todas las relaciones humanas y supone conducirse como cabria esperar de cuantos con pensamiento honrado intervienen en el trafico como contratantes.

\footnotetext{
${ }^{30}$ Resolucion , 46325 (Superintendencia de Industria y Comercio 31 de agosto de 2010)
} 
Este principio de buena fe se encuentra consagrado en el artículo 83 de la Constitución Política y se ha convertido hoy en día en un pilar fundamental en el desarrollo del derecho de obligaciones, contratos, y las relaciones mercantiles internacionales (Ravassa Moreno G. , 2004, pág. 463), así la ( Convención de las Naciones Unidas sobre los Contratos de Compraventa Internacional de Mercaderías, 1980) lo consagra en su art. $7^{\circ}$, los (Principios UNIDROIT para los contratos comerciales internacionales , 2004) en su art. 1.7. que introduce el concepto de buena fe negocial, que supone el establecimiento de una buena fe que ya será apreciada con criterios meramente subjetivos, sino que adiciona a esta apreciación criterios objetivos generales denominados criterios comerciales razonables de lealtad negocial de donde derivan los deberes de confidencialidad y de no negociar de mala fe.(Oviedo Alban, 2003, pág. 483).

En nuestra legislación el principio de la buena fe se encuentra establecido en el artículo 1603 del código civil y en el artículo 871 del código de comercio Colombiano, que señala "los contratos deberán celebrarse y ejecutarse de buena fe, y en consecuencia, obligarán no sólo a lo pactado expresamente en ellos, sino a todo lo que corresponda a la naturaleza de los mismos, según la ley, la costumbre o la equidad natural".

La violación de los postulados y principios que la buena fe negocial, deriva para el deudor en una responsabilidad contractual; como lo sostiene el profesor italiano 
(Betti, 1969, pág. 104) La buena fe es un principio imprescindible e inseparable de las etapas de la relación contractual.

(Jordano Fagra, 1987, pág. 31) señala que el deber de buena fe implica a demás de las prestaciones del contrato, que en la actividad del cumplimiento no resulte daño por obra de la contraparte, es decir que el contratista está obligado además de sus prestaciones concretas efecto del contrato celebrado (dar hacer o no hacer) a una prestación adicional de contenido ético, el deber de buena fe. Incurriendo en responsabilidad contractual al causar daño en un interés distinto de la prestación, pero ligado a la actividad de cumplimiento (Arrubla P. J. , 2008, pág. 432). Concebida como lo acabamos de expresar la buena fe objetiva, es fuente de integración contractual, toda vez que a los contratantes les serán exigibles ciertos deberes de conducta derivados de la necesidad de dar al negocio jurídico efectividad de conformidad con la finalidad perseguida por las partes, haciendo todo aquello que es necesario para hacer llegar a la contraparte el pleno resultado útil de la prestación debida.

Debemos empezar por mencionar que entre los elementos que componen el fondo de comercio y que se encuentran enunciados en el artículo 516 del Código de Comercio Colombiano se encuentra, el derecho a impedir la desviación de la clientela, a la protección de la fama comercial, a las invenciones o creaciones industriales 0 artísticas que se utilicen en las actividades del establecimiento. Todos estos elementos sensibles, dado el conocimiento que el 
enajenante tiene del fondo que transfiere, a no garantizar su entrega real y efectiva en el momento en que éste decidiere reinstalarse en rango de influencia del establecimiento transferido.

Estos elementos materializan la esencia del negocio mismo, y que no en todos los casos son susceptibles de una transmisión directa cuando se vende el establecimiento mercantil, es por ello como bien lo sostiene (Veleiro Reboredo, 2010, pág. 48) que se acepta la obligación impuesta al vendedor para hacer todo lo posible por traspasárselos al adquirente, que se hace efectiva fundamentalmente por medios indirectos a través del cumplimiento de dos tipos de obligaciones una positiva que suele materializarse en la entrega de listas de clientes y proveedores y una negativa que se materializa en el pacto de no competencia. Al respecto señala (Méndez, 2008, pág. 107 ) como el valor del establecimiento incluye también el de la organización como cualidad inseparable del mismo, la obligación de entrega del vendedor no se agota con la entrega o puesta a disposición de los distintos elementos integrantes de aquél, sino que comprende también la obligación de situar al adquirente en condiciones de utilizar y explotar esa organización y el crédito del establecimiento respecto de la clientela. No es suficiente con la entrega; el vendedor tiene respecto del comprador específicas obligaciones de colaboración: por un lado, el vendedor tiene la obligación de informar lealmente al comprador sobre la organización interna del establecimiento y sus posibilidades de actuación en el mercado, y por otro, debe abstenerse de realizar actos que ocasionen o sean susceptibles de 
ocasionar una captación de clientela. Sobre el vendedor pesa, pues, una obligación de no competencia, como medio indirecto para no destruir la organización y la clientela

Es claro que en muchas clases de establecimientos comerciales suele generarse algún tipo de vínculo entre su clientela y el empresario enajenante, lo cual implica que de alguna manera esta clientela va a mantenerse fiel al vendedor, sin que decir de los conocimientos del negocio, que por más que los comparta con el adquirente no puede desligarse totalmente de ellos; situaciones que ante la reinstalación de ese vendedor claramente permitirían el aprovechamiento indebido de los derechos traspasados, menguando el avviamiento, arruinando la expectativa que tenía el comprador que esa clientela siga acudiendo al establecimiento a demandar los bienes y servicios, e impiden la real transferencia del fondo como unidad económica obligación principal en este contrato.

Si se transfiere con el establecimiento ese derecho a impedir la desviación de la clientela, tal derecho no solo es exigible a terceros competidores, sino aun con mas veras al propio enajenante quien ha recibido un precio por ello y debe garantizar la tradición efectiva del fondo, (Mármol Marquis, 1985, pág. 174) Sostiene, que nada se opone a concluir que existe un derecho sobre la clientela el cual es absolutamente traspasable junto con los otros elementos que componen el fondo comercial; no es cierto que la compraventa implique solamente obligaciones de dar, pues genera también las obligaciones de hacer contenidas en las garantías de evicción vicios ocultos, y la obligación de no hacer resumida en la 
abstención por parte del vendedor de todo acto que perturbe a su propio comprador. Idea que es reforzada por los planteamientos del profesor (Morles Hernández, 2007, pág. 219) quien al referirse sobre la (Ley 11.867 Transferencia de fondos de comercio, 1934) señala que el derecho sobre la clientela como elemento constitutivo del fondo de comercio, se concreta en la expectativa que tiene el adquirente que las personas seguirán acudiendo al fondo de comercio a demandar los bienes o servicios que este provee, por ello la jurisprudencia y la doctrina han proclamado que la inhibición de competir se presume en el caso de la transferencia del establecimiento. (Broseta Pont, 1994, pág. 108) señala como aunque las partes no hayan pactado la inhibición de competencia el vendedor del fondo está igualmente en la obligación de abstenerse de la misma, lo anterior se desprende de la naturaleza del negocio de transmisión y la buena fe que debe presidir la ejecución de los contratos.

(Ravassa, 2001, pág. 291) Señala como para el derecho francés se considera que la obligación de no competencia, resulta de la naturaleza del contrato, por lo menos cuando el vendedor intenta desviar en provecho de su nueva explotación la clientela que cedió; y justifica en el derecho colombiano la obligación de no competencia del vendedor sobre la base de la buena fe contractual. A juicio de (Venegas, Cárdenas, \& Mantilla, 2009, pág. 172) el derecho a impedir la desviación de la clientela y la protección de la fama comercial comporta un especial deber de concurrencia que debería ser cabalmente regulado en el 
contrato de transferencia y a falta de regulación la obligación de no concurrencia se reconduce en una obligación de saneamiento

En consecuencia con lo expuesto a lo largo de este capítulo, a pesar que la legislación Colombiana no trae expresamente la inhibición de competencia del vendedor de un establecimiento de comercio a favor del comprador, consideramos que dada la especial naturaleza de los elementos que componen el fondo entre ellos el derecho a impedir la desviación de la clientela, el uso del Knowhow, el goodwill y otros, solamente con la abstención se garantiza una tradición efectiva del fondo como unidad económica, obligación que naturalmente se le exige al vendedor y que desarrolla claramente ese principio de buena fe objetiva integradora del contrato, en la medida que presupone el deber de ese vendedor de hacer todo todo aquello necesario para hacer llegar a la contraparte el pleno resultado útil de la prestación debida, lo cual depende indefectiblemente del cumplimiento de esta obligación de no hacer. Concluyéndose para nuestro juicio, que la inhibición de competencia constituye una obligación no solo necesaria en el contrato de compraventa de fondos de comercio, sino que además hace parte de la naturaleza del contrato y como tal aunque no haya sido pactada por las partes es exigible al vendedor, caso en el cual corresponderá al juez fijar los criterios de proporcionalidad que correspondan según el caso concreto y de acuerdo con los criterios que estudiaremos más adelante.

\subsection{Necesidad cuando hay venta parcial del establecimiento de comercio}


La unidad funcional del establecimiento de comercio ha querido preservase por la legislación Colombiana en los casos de su enajenación a cualquier título(Narváez Garcia, 2002, pág. 123), la cual se presume hecha en bloque sin necesidad de especificar detalladamente los elementos que lo integran articulo 525(Codigo de Comercio Colombiano decreto ley 410, 1971), en un sentido similar fue redactado el 517 ibídem, señalando que en el momento en que haya de procederse a la enajenación forzada de un establecimiento de comercio se preferirá la que se realice en bloque o en su estado de unidad económica. Sin embargo la legislación también permite que este sea desmembrado, pudiéndose enajenar los bienes o derechos que lo conforman de manera separada (Peña Nosa, 2006, pág. 230). Lo cual plantea un nuevo interrogante, ¿cuáles de los elementos conforman la esencia del establecimiento y su transmisión implica igualmente la del fondo, y cuáles de ellos podrían ser parte de la enajenación o no, sin que ello implique la transferencia del fondo?. En otros términos si existe una enajenación parcial de los bienes que componen un establecimiento comercial cuales de estos determinan la real transferencia del mismo y cuales supondrían una mera enajenación de bienes, que por sí, no se entienden como transferencia del establecimiento, y dentro del cual no se justifica una clausula de no competir.

Para ambientar el asunto de estudio traemos a colación el asunto tratado por La Cámara Nacional de Apelaciones en lo Comercial de Argentina (fallo plenario Arrese, Edmundo M. C. Y OTRO , 1938) ${ }^{31}$ Quien señaló que los elementos que

\footnotetext{
${ }^{31}$ fallo plenario Arrese, Edmundo M. C. Y OTRO , 10-662 (Camara Nacional de Apelaciones en lo Comercial 5 de diciembre de 1938)
} 
componen el establecimiento, pueden ser esenciales a la universalidad al punto que la transmisión de uno sólo de ellos implique la del fondo e, inversamente, que la transmisión de la mayoría de esos elementos no importe una transferencia de la universalidad

Aunque la ley colombiana no los diferencia, es importante para el estudio que nos ocupa señalar, que la doctrina ha considerado que el establecimiento o fondo de comercio se encuentra compuesto por unos elementos estáticos y otro funcional o dinámico. Los elementos estáticos pueden consistir en bienes o derechos que integran el establecimiento de comercio y que pueden inclusive faltar parcialmente o por completo, sin que por ello el fondo pierda su identidad económica y jurídica. Estos elementos pueden ser corporales como las mercancías, el mobiliario y las instalaciones; o incorporales como el derecho al nombre o enseña, al contrato de arrendamiento, al uso exclusivo de determinadas marcas u otros bienes de la propiedad industrial etc.

El elemento dinámico o funcional, a diferencia de los anteriores está concebido como la capacidad del fondo comercial de producir frutos o utilidades, Ese elemento funcional se concreta en las ganancias que produce el fondo con relación al capital, es el que la doctrina italiana denomina avviamento, o achalandage en el derecho Francés. El elemento funcional, al contrario de los elementos estáticos, deberá existir aunque el fondo sea reducido a su mínima expresión, pues es este el que cohesiona y da sentido a los demás elementos, 
haciéndolos parecer como una sola unidad económica, es por ello que se considera que no darse el mismo no existiría como tal el fondo de comercio.

El aviamiento para (Fontanarrosa, 1997, pág. 229) es la capacidad de la hacienda, por su composición y por el impulso dado a su organización de producir económicamente y brindar beneficios al empresario. A esos elementos y factores se agregan otros, tales como la ubicación del negocio, la habilidad, experiencia y prestigio del empresario, que indudablemente influyen en la capacidad o aptitud de la empresa. (Pinzón, 1985, pág. 178) Considera al avviamento el producto de la inteligencia humana aplicada a hacer que de un conjunto heterogéneo de elementos resulte una combinación apta para la obtención del fin deseado, que es un resultado económico, la prestación de cosas o servicios y se exterioriza en el aseguramiento de una clientela.

En conclusión lo esencial, para considerar un fondo de comercio, radica en el elemento dinámico o funcional, por cuanto los elementos estáticos pueden existir en mayor o menor grado y aun faltar por completo, desaparecer siendo o no remplazados sin que por ello el fondo pierda su identidad económica y jurídica (Fernandez, 1961, pág. 148).

Algo que siempre hay que tener presente es que en la enajenación de un fondo de comercio quien lo transfiere, cede una organización destinada a producir beneficios económicos, independientemente de su actitud(Zunino, 1982, pág. 152); entonces no siempre que se transfiere alguno o algunos de los elementos 
que integran el fondo de comercio puede decirse que igualmente se transmite su unidad.

La legislación Europea al respecto señala, que las cláusulas inhibitorias de la competencia no pueden considerarse necesarias si, en realidad, el traspaso se limita a activos materiales (como terrenos, edificios o maquinaria) o a derechos exclusivos de propiedad industrial y comercial (cuyos titulares pueden emprender de inmediato acciones legales contra las infracciones que pueda cometer el cedente de dichos derechos) (Comunicación de la Comisión sobre las restricciones directamente vinculadas a la realización de una concentración y necesarias a tal fin C56/03., 2005).

Entonces para poder determinar, cuando la transmisión parcial de algunos elementos que conforman el establecimiento, presupone la de la universalidad del fondo, deberá estarse a criterios que permitan determinar si el enajenante conserva la posibilidad de continuar con la actividad mercantil y la clientela del negocio, lo que a mi juicio implica la transferencia necesariamente del el elemento funcional, el derecho sobre la clientela y el Knowhow. Una ilustración clara del asunto la expone el profesor (Supervielle, 1953, pág. 143) En su libro El establecimiento comercial: noción, disciplina, naturaleza, diciendo que la manifestación más clara e inequívoca de la extinción del fondo de comercio, está en la cesación de la explotación que hace desaparecer la clientela. El cese destruye el elemento que vincula y crea la hacienda, aun cuando puedan subsistir las unidades materiales que la componen. 
La Cámara Nacional Civil sala A de la Argentina en fallo (fallo Mastellone de Marino, Gladys c/Mastellone, Huber, 1985) ${ }^{32}$ Para definir, entonces, cuando la transferencia de uno o varios elementos supone la del fondo de comercio como universalidad, considero que existe transferencia cuando con motivo de la enajenación de ciertos elementos, el vendedor quede privado de los medios para continuar el giro negocial de la misma forma en que lo hacía habitualmente.

Nótese que acertadamente el análisis centra la atención en la situación del transmitente del fondo, no siendo indispensable la efectiva continuación del negocio por parte del adquirente, En otras palabras, la tradición del fondo de comercio se materializa cuando el enajenante transfiere aquellos elementos indispensables para el desarrollo de la actividad mercantil y en consecuencia se ve impedido de continuar el negocio, sin importar la suerte que con este cuente el adquirente, la prueba más contundente de que el fondo como universalidad no ha sido transferido, se da cuando la transmisión de ciertos elementos del establecimiento no impida al transmitente continuar con su explotación.

Un ejemplo de lo expuesto lo encontramos en el (fallo Webespacios Com. S.A. c/B.B.D.O. Argentina S.A. , 2007) ${ }^{33}$ en el cual la Cámara de Apelaciones en lo Comercial de Argentina resuelve sobre la transferencia de un fondo de comercio a

\footnotetext{
${ }^{32}$ fallo Mastellone de Marino, Gladys c/Mastellone, Huber, L. L. 1986 (Cámara Nacional Civil de Argentina sala A 14 de mayo de 1985)

${ }^{33}$ fallo Webespacios Com. S.A. c/B.B.D.O. Argentina S.A. , 115365 (Camara Nacional de Apelaciones en lo Comercial Sala A 19 de julio de 2007)
} 
"BBDO Argentina S.A." señalando: Tras la celebración de los actos a través de los cuales, según la actora, se habría concretado la transferencia del establecimiento mercantil, su titular continuó explotando el mismo negocio, en el mismo lugar, lo cual demuestra que la transmisión de elementos que pudo haberse realizado no significó la transferencia del fondo de comercio como universalidad, siendo inaplicable al caso, en consecuencia, lo prescripto por la ley especial que regula este tipo de transferencias... Así mismo, he destacado más arriba que la efectiva transferencia de la clientela, como hecho de la realidad, puede servir como pauta interpretativa para determinar si la transferencia -voluntaria- de otros elementos representa o no la transferencia del fondo de comercio como universalidad... En resumidas cuentas, y como corolario de lo hasta aquí expuesto, debe concluirse que no ha mediado transferencia ni del nombre, ni de los clientes ni del personal de "Ratto/B.B.D.O. S.A." a "B.B.D.O. Argentina S.A." y que, aun cuando alguno de estos elementos hubiese sido efectivamente transferido, dicha transferencia no habría implicado la del fondo de comercio en el que la primera de estas sociedades desarrollaba su actividad. Ello, por la sencilla razón de que "Ratto S.A." siguió explotando el mismo establecimiento comercial que la actora dice transferido.

Solamente cuando efectivamente haya un desprendimiento por parte del enajenante de aquellos elementos esenciales para el adecuado funcionamiento del fondo o la Empresa como unidad económica, que le impiden al adquirente continuar ejerciendo la misma actividad independientemente del éxito o no del adquirente, es posible pactar válidamente clausulas de no competir. El tribunal de la defensa de la competencia de España en (informe , 2006 ) $^{34}$ mediante el cual conceptuaba sobre la adquisición de la totalidad del capital social de Europa Ferrys, S.A. y Viajes Eurotras, S.A. al considerar que la adquisición no implicaba la

\footnotetext{
${ }^{34}$ informe , C97/06 (TRIBUNAL DE DEFENSA DE LA COMPETENCIA 14 de junio de 2006 )
} 
tradición de la clientela, tampoco exista cesión de conocimientos técnicos que fuesen previamente desconocidos, la inhibición de la competencia no era necesaria a tal fin y representa una restricción no indispensable para garantizar la cesión al comprador del valor íntegro de los activos transferidos.

Consideramos que para que pueda existir la enajenación parcial de un fondo de comercio debe incluirse todos aquellos elementos que suponen conservar la actividad comercial con la aprehensión de la clientela habitual y la posibilidad de atracción de nueva, la clientela es un elemento indispensable para concebir el establecimiento como tal (Figueroa Yáñez, El Patrimonio, 1997, pág. 611) es por ello que coincidimos con (Fernandez Madrid, 1996, pág. 109)al afirmar que en La transferencia de un fondo de comercio, no debe excluir a la clientela o la llave por ningún motivo, ya que éstos son los elementos incorporales caracterizantes de la existencia de un negocio en marcha, que es lo transmitido por esta vía.

Al respecto el derecho económico de contratos (Mascareñas Perez-Iñigo, 1993, pág. 62) Considera que si el objeto enajenado es un establecimiento de comercio y no uno o varios de sus elementos constitutivos, las partes hicieron una valoración económica en la que pretendieron medir la eficacia a partir de los patrones organizativos el establecimiento y su entorno. De esta manera cuando hablamos de valoración económica de un establecimiento para su enajenación esta estará compuesta por dos sumas, el valor de sus elementos 
independientemente considerados por una parte, y el valor de la organización introducida por el empresario (García-Muñoz, 2001, pág. 259)

De lo anterior podemos concluir que la el avviamiento y la clientela son elementos que indudablemente son inseparables del establecimiento lo dotan de ese elemento funcional, entonces la enajenación de elementos que no presuponga la transferencia efectiva del elemento funcional, no puede considerarse como la de la universalidad del fondo, sino como la mera venta de elementos separados que lo componen, donde no cabe la posibilidad de pactar clausulas de no competencia, posibilidad que solo surge con la transferencia del establecimiento de comercio.

\section{Proporcionalidad}

Si bien es cierto que queda demostrada la necesidad de las clausulas de no competencia en este tipo de actuaciones, tales limitaciones no pueden ser desproporcionadas y en consecuencia la restricción que implica la clausula de no competencia, no debe ir más allá de lo necesario para garantizar su finalidad. Este carácter exige un cierto ajuste entre la causa y el efecto que habitualmente se materializa en el factor inversiones-tiempo (Martí Miravalls J. , 2008, pág. 345); la necesidad de la restricción para la realización de la operación principal justifica la presencia de la clausula restrictiva pero, al mismo tiempo limita su alcance al requerir que sea lo menos restrictiva de la competencia posible sin merma de la finalidad económico - jurídica que le es propia (Miranda Serrano L. M., 2000, pág. 4). Es decir que el pacto de no-competencia no puede configurarse de manera 
arbitraria, sino que debe circunscribirse estrictamente a su finalidad, que no es otra que la de consolidar en la persona del adquirente, la clientela, el knowhow, y otros derechos no susceptibles de transferencia directa, que ya tenía consolidados el tradente.

Como lo sostiene (Olavarria, 1970, pág. 106) las clausulas de no competencia se tratan de un compromiso que no solo es frecuente sino conveniente insertar en las escrituras de transferencia de los establecimientos de comercio, las cuales deberán estar limitadas al giro del establecimiento, por un determinado tiempo y en un determinado radio, pues extendidas en termino y generalizadas a toda clase de trafico podría atentar contra la libertad del comercio.

Su razonabilidad o proporcionalidad debe ser evaluada entonces, teniendo en cuenta que este el pacto solo busca dotar de efectividad al contrato de compraventa del fondo, y solo se entenderá razonable en la medida que sus alcances se circunscriban a lo que se considere absolutamente necesario para lograr esa finalidad.

La proporcionalidad de las clausulas de no competencia es evaluada por los tribunales desde varios aspectos, su duración, el ámbito geográfico, el alcance y su contenido, como lo señala (Comunicación de la Comisión sobre las restricciones directamente vinculadas a la realización de una concentración y necesarias a tal fin C56/03., 2005) a la hora de determinar si una restricción es necesaria o no, no sólo conviene tener en cuenta su naturaleza, sino que también hay que asegurarse de que su duración, contenido y ámbito geográfico de 
aplicación no exceden de lo que requiere razonablemente la realización de la concentración. Cuando existan alternativas de eficacia idéntica para lograr el objetivo legítimo apetecido, las empresas deberán escoger la que, desde un punto de vista objetivo, restrinja menos la competencia.

Al respecto el Tribunal de Defensa de la Competencia,(informe, 1993) ${ }^{35}$, asumiendo los criterios de la Comisión Europea, consideró que tales pactos no deben contener más restricciones que las objetivamente necesarias para la transferencia plena del establecimiento mercantil, ni realizarse en perjuicio de terceros. Este mismo Tribunal mediante (Resolución 457,2000$)^{36}$ en la que resuelve sobre la nulidad de unas clausulas de no competencia con duración y ámbito geográfico ilimitado, señaló que estos pactos de no competencia se consideran necesarios, pero han de limitarse a lo imprescindible para la transferencia del activo.

En Latinoamérica, La (Comision federal de la Competencia Economica de Mexico , $1995)^{37}$ en su informe correspondiente a los años 1993- 1994 señalo, que los acuerdos de no competir serán válidos, desde la perspectiva de competencia, siempre y cuando estén limitados en cuanto a las personas que quedan obligadas, el ámbito espacial que rige la disposición, los productos o servicios a que se refiere, y el tiempo durante el que estará vigente la obligación. En igual sentido la

\footnotetext{
${ }^{35}$ informe, expediente 40/92 (Tribunal de defensa de la Competencia 2 de marzo de 1993).

${ }^{36}$ Resolución 457 , Expte. 457/99, Hardi International (Tribunal de Defensa de la Competencia marzo de 27 de 2000)

${ }^{37}$ Informe Anual, 1993-1994 (Comision Federal de Competencia Económica México 01 de enero de 1995)
} 
Superintendencia de Industria y Comercio de Colombia señalo que las clausulas inhibitorias de la competencia están justificadas solo con el objeto de hacer posible la operación, cuando su duración, su ámbito geográfico su contenido y las personas sujetas a ellas no van más allá de lo razonablemente necesario para lograr ese objetivo (Resolucion, 2010) ${ }^{38}$. Analizaremos a continuación la proporcionalidad de estas clausulas en contratos de venta de fondos de comercio desde estos aspectos.

\subsection{Duración}

Una clausula de no competencia no es proporcional si no limita su duración. Para (Lopez Mesa, 2006) una cláusula no razonables es aquella que se pacta a 99 años, lo que para él equivale a una ausencia de limitación. "En escala de la vida llamada activa, un siglo es casi una eternidad

Si bien es cierto en que la doctrina ha considerado la duración de una clausula de no competencia como uno de los factores que determinan su razonabilidad en la enajenación de fondos de comercio, no existe un criterio unificado que permita señalar un término de la misma. Legislaciones como la italiana artículo 2557 del código civil y la Brasilera en el articulo 1147 Código Civil, establecen un plazo de 5 años para inhibir de la competencia al vendedor, la (Comunicación de la Comisión sobre las restricciones directamente vinculadas a la realización de una

\footnotetext{
${ }^{38}$ Resolucion , 46325 (Superintendencia de Industria y Comercio 31 de agosto de 2010)
} 
concentración y necesarias a tal fin C56/03, 2005) ha señalado que para el caso de cesión de empresas las clausulas inhibitorias de la competencia están justificadas durante un máximo de tres años cuando la cesión de la empresa incluye la transferencia de la clientela fidelizada como fondo de comercio y los conocimientos técnicos, y cuando solo se transfiere el fondo de comercio dichas clausulas están justificadas por periodos de dos años (Decision , 1999). ${ }^{39}$

En Argentina la Comisión Nacional de defensa de la competencia ha sostenido que la duración temporal permitida de una clausula inhibitoria de la competencia, debe restringirse a un plazo que permita razonablemente al adquirente asegurar la transferencia de la totalidad del valor de activos y proteja su inversión pudiendo variar según las particularidades de cada operación(Dictamen de Concentracion , 2001). ${ }^{40}$ En el mismo sentido el Tribunal de Defensa de la Competencia Español en su(Informe, 1998$)^{41}$ estimó que no existe una norma absoluta en cuanto a la duración de los pactos de no competir y suele depender del producto afectado y de las circunstancias de cada caso, sin embargo siguiendo el criterio de la Comisión Europea ha considerado que la duración de los pactos de inhibición de la competencia no deberá superar dos años en el caso de que se transfiera el fondo de comercio y tres años en el caso de que haya transmisión del fondo de comercio y know-how

\footnotetext{
${ }^{39}$ Decision , IV/M 1482 KingFisher/Grosslabor (Comision Europea 12 de abril de 1999)

${ }^{40}$ Dictamen de Concentracion , 06401216/2000 (Comisión Nacional de Defensa de la Competencia Argentina 27 de marzo de 2001)

${ }^{41}$ Informe (Tribunal de Defensa de la Competencia de España 25 de marzo de 1998)
} 
En Colombia no existe un referente doctrinal o jurisprudencial que permita establecer el término de duración aceptado para este tipo de clausulas. Sin embargo debemos señalar que los plazos impuestos a este tipo de estipulaciones contractuales deberán estar subordinados a la efectiva protección de los activos del establecimiento de comercio enajenado, por lo cual su duración no necesariamente puede ser estandarizada dependiendo en cada caso de las circunstancias que rodean la transmisión de estos activos. El único referente acerca del tiempo que puede tardar la consolidación de un establecimiento de comercio en la legislación Colombiana, es el artículo 518 del código de comercio que determina que después de dos años el empresario constituye su derecho a la renovación del contrato de arrendamiento del local comercial, por lo cual podría partirse de este término para señalar al igual que la legislación Europea sobre la cual se acoge la teoría de las restricciones accesorias de la competencia en Colombia por la Superintendencia de Industria y Comercio(Resolucion , 2010) ${ }^{42}$, que la duración de una clausula de no competencia cuando se trate de la transmisión pura y simple de un fondo de comercio no puede exceder de dos años, tiempo en que se presume consolidado la universalidad del fondo.

Sin embargo este plazo no puede ser absoluto pues en algunas circunstancias, la inclusión de conocimientos técnicos de carácter reservado, la fidelización de la clientela transferida, secretos industriales u otra serie de derechos justifican una duración mayor. Así mismo lo ha considerado la Comisión Europea quien pese a

\footnotetext{
${ }^{42}$ Resolucion , 46325 (Superintendencia de Industria y Comercio 31 de agosto de 2010)
} 
haber establecido plazos de tres y dos años como lo señalamos anteriormente en algunos casos excepcionalmente consideró justificados plazos más largos $(\text { Decision , 2000 })^{43}$. El Tribunal de defensa de la competencia de España en (Resolucion , 2003) ${ }^{44}$ expreso que solo pueden justificarse periodos más largos cuando las partes puedan demostrar que la clientela va a mantenerse fiel al vendedor durante más tiempo o cuando la naturaleza del knowhow transferido justifique un periodo adicional de protección. En dicho caso este Tribunal en un contrato de arrendamiento de empresa con opción de compra considero que pese a que La duración del pacto (seis años) es más larga de la que señala la Comisión como suficiente para conseguir la adecuada transmisión de los conocimientos técnicos, la fidelización de la clientela y la efectiva cesión del personal y de la actividad pero, teniendo en cuenta que el contrato está en vigor desde el 1 de enero de 2002 y la duración del pacto coincide con la del periodo en que el comprador tiene opción de compra, puede, en este caso, admitirse esa duración mayor de la que, en principio, se considera suficiente.

En conclusión el termino de duración de una clausula de no competencia debe limitarse única y exclusivamente al periodo mínimo que le permita al adquirente de un fondo de comercio asegurar la transferencia de la totalidad del valor de activos y proteja su inversión, el cual como regla será de dos años cuando se transfiera solamente el establecimiento comercial y tres cuando además del fondo se incluyan conocimientos técnicos, sin embargo podrá ser superior cuando

\footnotetext{
${ }^{43}$ Decision , Comp/M 1980 Volvo - Renault (Comision Europea 1 de septiembre de 2000)

${ }^{44}$ Resolucion , Expte. A 313/02, Pacto Foodservice-Mercat (Tribunal de Defensa de la Competencia 8 de abril de 2003)
} 
circunstancias excepcionales del negocio así lo justifiquen en razón a la fidelidad de la clientela o la naturaleza de los conocimientos técnicos transferidos.

\subsection{El Ámbito Geográfico}

Otro de los puntos imprescindibles para determinar la razonabilidad de una clausula accesoria de no competencia es el ámbito geográfico, la doctrina ha sostenido que este tipo de pactos pierde su eficacia si no limita sus efectos en un territorio determinado en el que el fondo de comercio ejerce su radio de influencia, la restricción no puede exceder el ámbito geográfico en que produce efectos la convención principal, así si un determinado establecimiento de comercio solo tiene el mercado en una zona muy limitada de una ciudad, en caso de venta, la clausula de no competencia solamente podrá limitar su restricción a esta zona de influencia y no a toda la ciudad. La (Comunicación de la Comisión sobre las restricciones directamente vinculadas a la realización de una concentración y necesarias a tal fin C56/03, 2005) señala que el ámbito geográfico de aplicación de una clausula inhibitoria debe restringirse a la zona donde el vendedor ofrecía los productos o servicios de referencia antes del traspaso, pues se considera que no es necesario proteger al comprador de la competencia del vendedor en territorios en donde este no estaba presente y no ejercía ninguna influencia en el mercado, sin embargo se acepta que las clausulas de no competencia contemplen ampliación de territorios en los que el vendedor planeaba introducirse siempre y cuando hayan efectuado inversiones. 
El Servicio de Defensa de la Competencia Español en (Informe, 2007) ${ }^{45}$ mediante el cual se pronuncia acerca de la adquisición por parte de la empresa ZARDOYA OTIS S.A. de ASCENSORES ASPE. Señaló que el ámbito geográfico de aplicación de una cláusula inhibitoria de la competencia debe limitarse a la zona en la que el vendedor ofrece los productos o servicios de referencia antes del traspaso. Sin embargo, la empresa adquirida actúa exclusivamente en las Islas Baleares y en la provincia de Las Palmas, el mercado relevante es local no nacional, por lo que la cláusula de no competencia excede de lo que razonablemente parece necesario para salvaguardar el valor del negocio transferido.

La Comisión Nacional de Defensa Argentina (Dictamen de concentrancion, 2000) ${ }^{46}$ al analizar la concentración resultante de la venta del fondo de comercio de la empresa Swift Amour S.A. a P\&O LogisticsArgentina S A. solicitó a las partes reducir una clausula de no competencia cuya prohibición abarcaba toda la República Argentina, para reducirla únicamente al área de influencia del negocio transferido que para el caso se limito a 250 kilómetros de radio.

En igual sentido la justicia Brasilera ha desestimado causas de violación de la prohibición de no restablecimiento basada en el factor territorial, el Tribunal de

\footnotetext{
${ }^{45}$ Informe, N- 07033 ZARDOYA OTIS / ASCENSORES ASPE (Servicio de Defensa de la Competencia de España 2 de abril de 2007)

${ }^{46}$ Dictamen de concentrancion, 115 exp 064 008985/00 (Comision Nacional de Defensa de la Competencia Argentina 14 de Septiembre de 2000).
} 
justiça do Distrito Federal e dos Territórios en fallo de (Apelación interlocutoria, $2007)^{47}$ al resolver sobre la violación de la obligación de no concurrencia por el enajénate de un fondo de comercio denominado Bar Concentração señalo: aunque, en teoría el demandado pudo haber violado el artículo 1147 del Código Civil, los establecimientos de Bar Concentração y Beach Bar se encuentran en las diferentes regiones administrativas del Distrito Federal, el primero en el ala sur SQS 209, y otro en South Lake - IQ 09. Por lo tanto parece que se encuentran en diversas regiones, y tienen clientes diferentes por la distancia geográfica que separa a los dos establecimientos dando por desestimada la violación a la obligación de no concurrencia.

En conclusión una clausula de no competencia debe estar limitada en cuanto al ámbito geográfico, no pudiendo extenderse más allá de la verdadera zona de influencia del fondo de comercio, es decir donde se entiende que el vendedor ha introducido sus productos o servicios, so pena de considerarse desproporcionado y restrictivo.

\subsection{Alcance}

Las clausulas de no competencia no pueden imponer restricciones a terceros sino sólo a la propia libertad de acción de los participantes de la transacción, así ha sido considerado por la doctrina internacional la (Comunicación de la Comisión

\footnotetext{
${ }^{47}$ Apelación interlocutoria, 20070020112024AGI (Tribunal de justiça do Distrito Federal e dos Territórios 14 de noviembre de 2007)
} 
sobre las restricciones directamente vinculadas a la realización de una concentración y necesarias a tal fin C56/03, 2005) al respecto señala que el vendedor puede comprometerse en nombre propio, en el de sus empresas filiales y de sus agentes comerciales, pero la imposición de esa obligación a otras personas es inadmisible. En igual sentido la Comisión Nacional de Defensa de la competencia de Argentina (Dictamen , 2008) ${ }^{48}$ señalo que las clausulas inhibitorias de la competencia No deben estar referidas a terceros sino sólo a la propia libertad de acción de los participantes de la transacción.

Estos pactos solo pueden limitar la competencia del vendedor y no de otras personas que no son parte dentro de la operación de enajenación, sin embargo cabe aclarar que cuando el enajenante sea una persona jurídica que ostente la calidad de matriz, se ha aceptado que la inhibición de competencia pueda también recaer sobre las filiales o subsidiarias de este, siempre y cuando sea necesaria tal extensión para garantizar la transferencia integra de los activos que componen el fondo. La Comisión de Defensa de la Competencia en (Dictamen, 2004) ${ }^{49}$ encontró adecuada una clausula de no competencia en la empresa la Controlante y matriz de la Vendedora (BellsouthCorporation) y cada una de las Vendedoras (Bellsouth Argentina y otras) se comprometen en nombre propio y en el de sus subsidiarias por un plazo de dos (2) años a partir de la fecha del cierre, a no operar, ni administrar, ni ser propietaria, en forma directa o indirecta cualquier

\footnotetext{
${ }^{48}$ Dictamen , 704 (Comision Nacional de Defensa de la Competencia 23 de Diciembre de 2008).

${ }^{49}$ Dictamen, 417 (Comision Nacional de Defensa de la Competencia 22 de dicembre de 2004).
} 
negocio de servicios de telecomunicaciones inalámbricas del tipo de los desarrollados por la Compañía Adquirida en ese país.

En síntesis la regla general es que el pacto que inhibe la competencia solo puede limitar su alcance al vendedor y comprador sin embargo en algunas ocasiones puede extenderse única y exclusivamente a agentes comerciales, filiales y subsidiarias, en la medida que están subordinados comercialmente a alguno de los contratantes y su inhibición sea esencial para la adecuada protección de los derechos.

Otro aspecto importante del alcance que tienen las prohibiciones de no competir, es la limitación al vendedor del fondo de realizar actividades que impliquen competencia a través de interpuesta persona por lo cual se limita el derecho del vendedor a participar del capital, ser gestor, adquirir o tener acciones en una Sociedad que compita con la empresa cedida, tal limitación se ha considerado necesaria y vinculada a la operación de enajenación del fondo según lo expresa la en el numeral 25 de la (Comunicación de la Comisión sobre las restricciones directamente vinculadas a la realización de una concentración y necesarias a tal fin C56/03, 2005); sin embargo debemos señalar que dicha prohibición solo es viable en la medida que la participación le permita intervenir en la dirección, gestión, administración o tener una influencia sustancial en el desarrollo de la actividad mercantil de la empresa competidora, de forma tal que pueda hacer uso en detrimento del comprador de los derechos transferidos con la enajenación del 
fondo de comercio. En razón a lo expuesto no seria proporcional extender esta prohibición a cualquier tipo de participación, pues cuando tales, solo tienen fines de inversión, que no le confieran directa o indirectamente funciones de dirección, o una influencia sustancial en la empresa competidora, tal prohibición resulta innecesaria y desproporcionada.

\subsection{Contenido}

Las clausulas inhibitorias de la competencia deben limitarse a los productos 0 servicios que ofrecidos a través del fondo de comercio transferido incluidas las versiones mejoradas y las actualizaciones de productos y los modelos sucesivos así como los servicios que constituyan la actividad económica de la empresa traspasada. La legislación europea ha considerado que es posible extender las clausula a los productos y servicios que se hallen en una fase avanzada de desarrollo en el momento de la transacción y los productos que ya estén totalmente desarrollados pero todavía no se hayan comercializado. No se considera razonable proteger al comprador de la competencia del vendedor en aquellos mercados de productos o de servicios en los que la empresa traspasada no operase antes del traspaso.

En desarrollo de esta interpretación mediante (Decisión , 2001) ${ }^{50}$ en la cual la Comisión Europea al analizar la adquisición de EIRCELL por parte de Vodafone

\footnotetext{
${ }^{50}$ Decisión , (COMP/M.2305 — Vodafone Group PLC/EIRCELL (Comision Europea 2 de marzo de 2001)
} 
Group PLC que contiene una clausula de no competencia para que EIRCEL por 3 años en Irlanda, autorizó la operación al considerar que la clausula de no competencia es accesoria a la concentración en la medida en que se relaciona con los servicios de telecomunicaciones móviles y es necesario para transferir el bien y el KnowHow.

Vale la pena para desarrollo del tema citar la doctrina de La Comisión Nacional de Defensa de la Competencia de Argentina, quien al respecto ha señalado que la restricción de inhibición de competencia en cuanto a su contenido sólo debe limitarse a los productos o servicios que constituyan la actividad económica de la empresa o parte de empresa transferida, ya que no resulta razonable, desde el punto de vista de la competencia, extender la protección brindada por este tipo de cláusulas a productos o servicios que el vendedor no transfiere o no comercializa (Dictamen , 2003). ${ }^{51}$ Este mismo tribunal en (Dictamen, 2001) ${ }^{52}$ objetó una clausula de no competencia celebrada en medio de la operación de concentración entre Interco Argentina S.A. y Tele Monitoreo S.A. pues en esta se señalaba que la vendedora se comprometía a no vender al grupo de clientes transferidos, por ningún medio, ya sea directa o indirectamente ni a auxiliar a terceras personas en la venta de cualquier servicio similar o no al de las cuentas de monitoreo. A juicio de la Comisión dicha clausula quedo sujeta no solo a los productos que se ofrecían a través de los fondos de comercio transferidos sino a otros que le fueren

\footnotetext{
${ }^{51}$ Dictamen , 373 (Comision Nacional de Defensa de la Competencia 16 de diciembre de 2003)

${ }^{52}$ Dictamen, 239 (Comision Nacional de Defensa de la Competencia 27 de Marzo de 2001)
} 
similares ampliando la actividad específica objeto de la operación, lo cual no la hace razonable desde el punto de vista de la competencia.

En conclusión para entender razonablemente valida una clausula de no competencia en la enajenación de un fondo de comercio, su contenido únicamente podrá abarcar aquellos productos o servicios en los que se haya dedicado en desarrollo de su actividad comercial pudiendo extender la clausula únicamente a los productos y servicios que se encuentren en una fase avanzada de desarrollo en el momento de la transacción y los productos que ya estén totalmente desarrollados pero todavía no se hayan comercializado.

\subsection{Tratamiento de la falta de proporcionalidad}

Resta preguntarnos entonces cual debe ser el tratamiento jurídico de aquellos pactos de no competencia que siendo accesorios, subordinados y necesarios a la operación de enajenación del fondo de comercio, no son proporcionales, en la medida que dichas estipulaciones exceden los parámetros de razonabilidad expuestos, en cuanto a su contenido, duración, alcance, ámbito geográfico o no son determinados por las partes.

La primera respuesta parecería lógica pues tenderían a ser restrictivos y por ende nulos; sin embargo en este contrato en particular, al ser la inhibición de competir una obligación necesaria y de la naturaleza que permite asegurar la efectiva 
tradición del fondo, mal podría la falta de proporcionalidad hacer nugatoria esta obligación que constituye la garantía de la prestación principal del contrato.

Para ser más claros haremos el siguiente ejemplo: Javier vende a Álvaro su famoso restaurante de carnes ubicado en Tunja, y estipulan dentro del contrato un pacto de no restablecimiento, por el cual Javier se obliga a no realizar actividades comerciales relacionadas con todo el sector de las comidas por un periodo de ocho años y en todo el territorio Nacional. Claramente este tipo de estipulación excede lo que razonablemente se pretende amparar con el pacto y seria restrictivo de la competencia, sin embargo si declaramos la nulidad absoluta del pacto, se entendería que el tradente queda liberado de su obligación negativa de competencia, pudiendo en consecuencia ubicar un nuevo restaurante a unas pocas casas del anterior y el adquirente ve como eventualmente no podría ejercer una acción que lo proteja contra la competencia de ese vendedor que utiliza el Knowhow, la clientela y otros bienes que hacían parte del fondo de comercio enajenado. Lo cual ciertamente rompería como lo señalamos este equilibrio.

De el anterior ejemplo queremos resaltar como la presencia de la accesoriedad, la subsidiaridad y la necesidad, y en especial esta ultima como requisitos del pacto de no competencia, permiten la creación de un derecho y un deber contractual legitimo, que para el caso de estudio es el de inhibir la competencia del vendedor para garantizar la efectiva tradición del fondo comercial, derecho que existiendo debe matizarse para ser lo menos restrictivo posible lo cual se logra a través de la proporcionalidad de la misma. 
Entonces debemos a nuestro juicio diferenciar aquellos requisitos que hacen la clausula de no competir nula por completo pues imposibilitan el surgimiento de un derecho legitimo para inhibir la competencia, de aquellos que matizan el derecho para evitar su desbordamiento, papel que juega la proporcionalidad a través de la limitación del derecho de no sufrir competencia de su vendedor en unas determinadas condiciones de tiempo modo y lugar, los cuales no pueden al no ser determinantes en el surgimiento de la obligación de no competir invalidarla plenamente.(Lorenzetti, 2005, pág. 323)Considera que a fin de no juzgarla abusiva la clausula de no competencia, se entiende que debe tener un plazo limitado, un espacio y una actividad definidos, ya que de lo contrario afectaría genéricamente la libertad del deudor

Si nos encontramos ante la venta de elementos que pueden componer un fondo de comercio pero no la del fondo mismo como unidad económica, como lo expusimos previamente la falta de necesidad hará absolutamente nula la clausula. Pues en este aspecto la clausula no protege el interés trasmitido, el cual no exige ninguna abstención para su efectiva tradición y en consecuencia la declaratoria de nulidad de la clausula no afecta el real cumplimiento del contrato. Sin embargo cuando el contrato es de compraventa de un establecimiento de comercio la obligación de no competir es necesaria, accesoria, subsidiaria y adicionalmente constituye como lo hemos sostenido en este estudio un elemento de la naturaleza del contrato de compraventa del establecimiento comercial en la medida que 
garantiza efectivamente su tradición, por lo cual la falta de proporcionalidad no puede generar la nulidad de la inhibición de la competencia y en consecuencia extinguir la obligación del vendedor de manera absoluta, sino solo de aquello que exceda lo razonablemente requerido para garantizar la efectiva tradición, de otra forma tal decisión afectaría el real cumplimiento del contrato y generaría una situación inequitativa para el comprador. Al respecto (Garrigues J. , 1987, pág. 233) señala que cuando el pacto viola las limitaciones, cabe preguntarse si será nulo o deberá entenderse simplemente por sustituido por otro que respete tales limitaciones inclinándose por esta última solución. (Fernandez, 1961, pág. 81) Consideró que si las cláusulas son exhorbitantes pueden ser reducidas a sus justos términos; así mismo se ha entendido por la doctrina Europea quienes al analizar operaciones de concentración en las que se contienen clausulas de no competencia que exceden la duración, el ámbito geográfico o su alcance han optado por reducirlas hasta lo estrictamente requerido para la protección del interés, a manera de ejemplo el Tribunal de Defensa de la Competencia Español en (Informe, 2004) al analizar una operación de venta de la empresa EuroStewart España a INVERSIONES TÉCNICAS URBANAS S.L en la que se establece un pacto de no competencia en el que la parte vendedora se compromete a no competir directa o indirectamente con la parte compradora en el sector de los servicios funerarios (especialmente en relación con la actividad de funerarias, velatorios y crematorios) ni a conceder cualquier licencia respecto de los nombres comerciales y marcas "Stewart" o "EuroStewart" en España en un período de 3 años desde la firma del contrato. Al considerar que el tiempo de la restricción era 
excesivo para la protección del derecho transferido juzgó conveniente que el ámbito temporal de aplicación de la cláusula de no competencia contenido en el contrato de compraventa se reduzca a dos años.

A nuestro juicio concluimos que en el contrato de compraventa de establecimiento comercial, al constituir la inhibición de la competencia por parte del vendedor una obligación indispensable y de la naturaleza del contrato, que asegura la efectiva tradición del fondo de comercio con todos los elementos que lo componen, la falta de proporcionalidad de la misma sea por ausencia de limitación o por exceso, no puede suponer la nulidad absoluta de la obligación del vendedor pues tal decisión impedirá la tradición efectiva del fondo ante la reinstalación. Por ello en este caso deberá el juez de conocimiento fijar sus alcances hasta las justas proporciones, declarando la ineficacia de aquello que exceda lo indispensable para la protección de los derechos transferidos.

Aclarando finalmente que el daño producido la violación de un pacto de no competencia en la enajenación de un establecimiento de comercio, genera, siempre una responsabilidad de tipo contractual ya sea como una consecuencia del deber de buena fe contractual (Rezzónico, 1998, pág. 530), o como resultado del deber de evicción. Existen los presupuestos de esta responsabilidad contractual como lo señala(Duci Claro, 1971, pág. 17) a saber: la presencia de un acreedor y un deudor, una obligación contractual y el incumplimiento por parte del deudor de dicha obligación, pues aquí el daño se origina precisamente en una clausula, accesoria, subsidiaria y necesaria, para la ejecución de esta clase de 
contratos, y lo que se reclama es precisamente la violación de la obligación contractual y no los actos de competencia propiamente dichos, por ende su fuente y responsabilidad obedece al contrato del cual emana aunque sus efectos sean posteriores al cumplimiento de la prestación principal.

\section{CONCLUSIONES}

La Doctrina de manera generalizada ha aceptado la necesidad de restringir la competencia por parte del enajénate al comprador de un fondo de comercio, sobre la base de impedir la "competencia desleal" del vendedor o de garantizar la efectiva trasferencia del bien.

La inhibición de competencia constituye una obligación no solo necesaria en el contrato de compraventa de fondos de comercio, sino que además hace parte de la naturaleza del contrato y como tal aunque no haya sido pactada por las partes es exigible al vendedor, caso en el cual corresponderá al juez fijar los criterios de proporcionalidad que correspondan según el caso concreto

La transferencia de un fondo de comercio se materializa y en consecuencia surge la posibilidad de pactar una clausula inhibitoria de la competencia, cuando efectivamente haya un desprendimiento por parte del enajenante de aquellos 
elementos esenciales para la universalidad, que le impiden continuar ejerciendo la misma actividad independientemente del éxito o no del adquirente.

La duración de una clausula de no competencia debe limitarse única y exclusivamente al periodo mínimo que le permita al adquirente de un fondo de comercio asegurar la transferencia de la totalidad del valor de activos y proteja su inversión, el cual como regla será de dos años cuando se transfiera solamente el establecimiento comercial y tres cuando además del fondo se incluyan conocimientos técnicos, sin embargo podrá ser superior cuando circunstancias excepcionales del negocio así lo justifiquen en razón a la fidelidad de la clientela o la naturaleza de los conocimientos técnicos transferidos

La inhibición de competencia en el contrato de compraventa de fondos de comercio debe estar limitada en cuanto al ámbito geográfico, no pudiendo extenderse más allá de la verdadera zona de influencia del fondo de comercio la cual puede ser local, nacional o mundial, es decir donde se entiende que el vendedor ha introducido sus productos o servicios, so pena de considerarse desproporcionado y restrictivo

El pacto que inhibe la competencia solo puede limitar su alcance al vendedor y comprador, sin embargo en algunas ocasiones puede extenderse única y exclusivamente a agentes comerciales, filiales y subsidiarias, en la medida que están subordinados comercialmente a alguno de los contratantes y su inhibición sea esencial para la adecuada protección de los derechos transferidos. 
La limitación al vendedor del fondo de participar del capital, ser gestor, adquirir o tener acciones en una Sociedad que compita con la empresa cedida se ha considerado necesaria y vinculada a la operación de enajenación del fondo, pero solo es viable en la medida que la participación le permita intervenir en la dirección, gestión, administración o tener una influencia sustancial en el desarrollo de la actividad mercantil de la empresa competidora.

Para entender razonablemente valida una clausula de no competencia en la enajenación de un fondo de comercio, su contenido únicamente podrá abarcar aquellos productos o servicios en los que se haya dedicado en desarrollo de su actividad comercial pudiendo extender la clausula únicamente a los productos y servicios que se hallen en una fase avanzada de desarrollo en el momento de la transacción y los productos que ya estén totalmente desarrollados pero todavía no se hayan comercializado.

En el contrato de compraventa de establecimiento comercial, al constituir la inhibición de la competencia por parte del vendedor una obligación necesaria y de la naturaleza del contrato, que asegura la efectiva tradición del fondo de comercio con todos los elementos que lo componen, la falta de proporcionalidad de la misma sea por ausencia de limitación o por exceso, no puede suponer la nulidad absoluta de la obligación del vendedor pues tal decisión impedirá la tradición efectiva del fondo ante la reinstalación. Por ello en este caso deberá el juez de conocimiento fijar sus alcances hasta las justas proporciones, declarando la 
ineficacia de aquello que exceda lo indispensable para la protección de los derechos transferidos.

\section{BIBLIOGRAFÍA}

Adame Goddard, J. (2001). ¿Deben Ser Válidas Las Cláusulas De No Competencia En El Derecho Mexicano? Boletin Mexicano de Derecho Comparado , 687-730.

Aguilar Álvarez De Alba, J. B. (2000). La Libre Competencia (Primera ed.). Mexico DF: Oxford.

Alessandri R, A., Somarriva U, M., \& Vodanovic H, A. (1998). Tratado de Derecho civil: Partes preliminar y general. Santiago: Editorial Juridica de Chile.

Arrubla P., J. (2008). Contratos Mercantiles Teoria general del Negocio Mercantil Tomo I. Bogota: Dike.

Betti, E. (1969). Teoría general de las obligaciones. (J. L. De Los Mozos, Trad.) Madrid: Revista de Derecho Privado. 
Broseta Pont, M. ,. (1994). Manual de Derecho Mercantil. Madrid: Tecnos.

Cabanellas De Las Cuevas, G. ((2005). Derecho antimonopólico y defensa de la competencia. BuenosAires: Heliasta.

Certad Maroto, G. (2007). Temas de Derecho Comercial. San José: Juritexto.

Creus Carreras, A., Amador Peñate, O., \& Pérez Olmo, G. (2006). Código de derecho de la competencia. Madrid: La Ley.

Díez-Picazo Y Ponce De León, L. (1963). La doctrina de los actos propios: un estudio crítico sobre la jurisprudencia del Tribunal Supremo. Barcelona: Bosch.

Duci Claro, C. (1971). Responsabilidad Civil. Santiago: Editorial Juridica de Chile.

Fernandez Madrid, J. C. (1996). Manual Práctico de Contratación Comercial, t. II. Buenos Aire: Errepar.

Fernandez, R. (1961). Código de Comercio Comentado (Vol. II). Buenos Aires: Depalma.

Figueroa Yáñez, G. (1997). El Patrimonio. Santiago: Editorial juridica de Chile .

Figueroa Yáñez, G. (1996). Repertorio de legislación y jurisprudencia Chilenas Tomo I. Santiago: Editorial Jurídica de Chile.

Fontanarrosa, R. (1997). Derecho comercial argentino, Parte general, Tomo I. Buenos Aires : Zavalia.

García-Muñoz, J. A. (2001). Derecho Económico de los Contratos. Bogota : libreria del profesional .

Garrigues, J. (1993). Curso de Derecho Mercantil Tomo I. Mexico : Porrua S A.

Garrigues, J. (1987). Curso de derecho mercantil1a. reimpr. de la 7a. ed. Bogotá: Temis.

Gaviria Gutierrez, E. (1985). Los conceptos de Empresa y Sociedad Unipersonal en el derecho mercantil y en el Código de Comercio Colombiano. Medellin: Camara de Comercio y Colegio de Abogados de Medellin.

Goldschmidt, R., Rodríguez, G., \& Ruiz, I. B. (2008). Curso de Derecho Mercantil . Caracas : Texto C.A. .

Gutierrez Zaldivar, A. (2001). Algunos problemas que plantean las transferencias de Fondos de Comercio. (Buenos Aires: La Ley. 
Jimenez Sanchez, G. (2009). Derecho Mercantil (13 edición ed., Vol. I). Barcelona: Ariel.

Jimenez Sánchez, G. J. (2003). Lecciones de Derecho Mercantil (octava ed.). Madrid: Tecnos.

Jordano Fagra, F. (1987). La Responsabilidad Contractual. Civitas : Madrid .

Larenz, K. (1958). Derecho de Obligaciones Tomo I. Madrid : Revista de Derecho Privado .

Lopez Mesa, M. (9 de Mayo de 2006). La responsabilidad Postcontractual . Recuperado el 3 de 12 de 2009, de el dial on line: www.eldial.com

Lorenzetti, R. L. (2005). Código Civil Comentado. Doctrina Jurisprudencia Bibliografía. Contratos. Parte Especial. Tomo I. Santa Fe : Rubinzal Culzoni Editores.

Mármol Marquis, H. (1985). Fundamentos de Derecho Mercantil. Caracas : Universidad Católica Andrés Bello.

Martí Miravalls, J. (2008). Las restricciones accesorias, necesarias y proporcionadas en el contrato de franquicia. Actas de Derecho Industrial y de Derechos de autor , 341-370.

Martinez Medrano, G. (2004). LIMITACIÓN CONTRACTUAL A LALIBERTAD DE COMPETIR (Transferencia deactivos comerciales y clausulas de no competencia). Recuperado el 21 de julio de 2011, de works.bepress.com: http://works.bepress.com/cgi/viewcontent.cgi?article=1039\&context=martinezmedr ano\&sei-

redir=1\#search=\%22Martinez\%20Medrano\%2C\%20\%C3\%A2\%C2\%80\%C2\%9CL a\%20competencia\%20desleal\%20 en\%20Argentina\%20\%28Una\%20aproximaci\% C3\%83\%C2\%B3n\%20la\%20competencia\%20desleal\%2

Mascareñas Perez-Iñigo, J. (1993). Manual de Fusiones y Adquisiciones de Empresas . Madrid : Mc Graw-Hill.

Méndez, A. (2008). Lecciones de Derecho Mercanti. Madrid: Civitas.

Miranda Serrano, L. M. (2000). Restricciones Accesorias y Practicas Colusorias. Derecho de los Negocios No 122 , 1-50.

Morles Hernández, A. (2007). Curso de derecho mercantil, Volumen 1 (9 ed.). Caracas : Texto C A. 
Narváez Garcia, J. I. (2002). La Empresa y el Establecimiento . Bogota : Legis.

Olavarria, J. (1970). Manual De Derecho Comercial. Barcelona : Clarasó.

Oviedo Alban, J. (2003). Compraventa Internacional de Mercaderias. Vniversitas, 463-552.

Pascual Y Vicente, J. (2002). Diccionario de Derecho y Economía de la Competencia en España y Europa. Madrid: Civitas.

Peña Nosa, L. (2006). De los contratos mercantiles Nacionales e internacionales. Bogota : ECOE Ediciones.

Pinzón, G. (1985). Introducción al Derecho Comercial. Bogota: Temis.

Principios UNIDROIT para los contratos comerciales internacionales . (2004). Roma, Italia.

Ravassa Moreno, G. (2004). Derecho Mercantil Internacional. Bogota: Ediciones Doctrina y Ley.

Ravassa, G. (2001). Derecho Comercial Tomo I. Bogota : Ediciones Jurídicas Gustavo Ibañez .

Raymundo L. Fernández, O. R. (1993). Tratado Teorico Practico de Derecho Comercial . Buenos Aires : Depalma.

Rezzónico, J. C. (1998). Principios fundamentales de los contratos. Buenos Aires: Astrea.

Schmidt, K. (1997). Derecho Comercial. Buenos Aires : Astrea.

Supervielle, B. (1953). El establecimiento comercial : noción, disciplina, naturaleza. Montevideo: Impresora Uruguaya .

Veleiro Reboredo, B. (2010). Mercado y Competencia. Madrid: El Derecho.

Venegas, A., Cárdenas, J. P., \& Mantilla, F. (2009). Estudios de Derecho Privado. Bogota: Universidad del Rosario.

Zunino, J. O. (1982). Fondo de Comercio: Regimen legal de su transferencia. Buenos Aires: Astrea. 


\section{REFERENCIAS JURISPRUDENCIALES Y DECISIONES DE ÓRGANOS DE COMPETENCIA}

Convención de las Naciones Unidas sobre los Contratos de Compraventa Internacional de Mercaderías. (11 de abril de 1980). Viena, Austria.

apelação, 9063300-75.2003.8.26.0000 (TRIBUNAL DE JUSTIÇA DO ESTADO DE SÃO PAULO 9 de febrero de 2011).

Apelación interlocutoria, 20070020112024AGI (Tribunal de justiça do Distrito Federal e dos Territórios 14 de noviembre de 2007).

Decision , IV/M 1482 KingFisher/Grosslabor (Comision Europea 12 de abril de 1999).

Decision , Comp/M 1980 Volvo - Renault (Comision Europea 1 de septiembre de 2000).

Decisión , (COMP/M.2305 — Vodafone Group PLC/EIRCELL (Comision Europea 2 de marzo de 2001).

Dictamen , 373 (Comision Nacional de Defensa de la Competencia 16 de diciembre de 2003).

Dictamen , 704 (Comision Nacional de Defensa de la Competencia 23 de Diciembre de 2008).

Dictamen, 239 (Comision Nacional de Defensa de la Competencia 27 de Marzo de 2001).

Dictamen, 417 (Comision Nacional de Defensa de la Competencia 22 de dicembre de 2004).

Dictamen de Concentracion , 06401216/2000 (Comisión Nacional de Defensa de la Competencia Argentina 27 de marzo de 2001).

Dictamen de concentracion, No 33 exp 064-020368/99 (Comision Nacional de Defensa de la Competencia de Argentina 20 de marzo de 2000).

Dictamen de concentrancion, 115 exp 064 008985/00 (Comision Nacional de Defensa de la Competencia Argentina 14 de Septiembre de 2000). 
fallo Mastellone de Marino, Gladys c/Mastellone, Huber, L. L. 1986 (Cámara Nacional Civil de Argentina sala A 14 de mayo de 1985).

fallo plenario Arrese, Edmundo M. C. Y OTRO , 10-662 (Camara Nacional de Apelaciones en lo Comercial 5 de diciembre de 1938).

fallo Webespacios Com. S.A. c/B.B.D.O. Argentina S.A. , 115365 (Camara Nacional de Apelaciones en lo Comercial Sala A 19 de julio de 2007).

Informe (Tribunal de Defensa de la Competencia de España 25 de marzo de 1998).

informe , C97/06 (TRIBUNAL DE DEFENSA DE LA COMPETENCIA 14 de junio de 2006 ).

informe, expediente 40/92 (Tribunal de defensa de la Competencia 2 de marzo de 1993).

Informe, C85/04 INTUR/EURO STEWART (Tribunal de Defensa de la Competencia España 20 de Octubre de 2004).

Informe, N- 07033 ZARDOYA OTIS / ASCENSORES ASPE (Servicio de Defensa de la Competencia de España 2 de abril de 2007).

Resolucion, Expte. A 313/02, Pacto Foodservice-Mercat (Tribunal de Defensa de la Competencia 8 de abril de 2003).

Resolucion , 46325 (Superintendencia de Industria y Comercio 31 de agosto de 2010).

Resolución, Expte. A 313/02, Pacto Foodservice-Mercat (Tribunal de Defensa de la Competencia España 8 de abril de 2003).

Resolución 457 , Expte. 457/99, Hardi International (Tribunal de Defensa de la Competencia marzo de 27 de 2000).

Sentencia de Apelacion, 0575775-3 (Tribunal de Justiça do Estado do Paraná 22 de septiembre de 2009).

\section{REFERENCIAS NORMATIVAS}


Codice civile . (1942 ). art 2555 art 2557. Roma, Italia .

Codigo Civil. (10 de enero de 2002). LEY No 10.406. Brasil.

Codigo de Comercio Colombiano . (27 de marzo de 1971). decreto ley 410 . Bogota, Colombia.

Comision federal de la Competencia Economica de Mexico . (1995). informe Anual. Mexico D F.

Comunicación de la Comisión sobre las restricciones directamente vinculadas a la realización de una concentración y necesarias a tal fin C56/03. (05 de marzo de 2005). Union Europea.

Ley 11.867 Transferencia de fondos de comercio. (9 de agosto de 1934). Buenos Aires, Argentina.

LEY 155 Por la cual se dictan algunas disposiciones sobre prácticas comerciales restrictivas. (14 de Diciembre de 1959). Bogota, Colombia.

Ley 1340 . (24 de julio de 2009 ). Colombia .

ley 222 . (20 de diciembre de 1995). Bogota, Colombia . 